\title{
Financialization of metal markets: Does futures trading influence spot prices and volatility?*
}

\author{
Herbert Mayer , Andreas Rathgeber, Markus Wanner \\ Professorship for Finance, Information \& Resource Management, Institute of Materials Resource Management, University of Augsburg, 86135 \\ Augsburg, Germany, `Correspondence: herbert.mayer@mrm.uni-augsburg.de, Tel.: +49 821598 - 3044
}

\begin{abstract}
The emerging financialization of commodity markets over the last decades has lead to an intense public and scientific debate about commodity investing and its impliçations. Although metal commodities are indispensable to industry and the economy, the influence of financialization on metal spot prices and in particular on respective volatility has been insufficientlystudied. Therefore, we attempt to contribute to existing literature by examining potential effects of the lead-ag relationship on futures trading activity of commercial and non-commercial market participants and cash prices and volatility for the major metal commodities: copper, gold, silver, platinum, and palladium. After analyzing Commitment of Traders (COT) reports from the U.S. Commodity Futures Trading Commission (CFTC) over a timeframe from January 1993 to Décember 2013, bi-directional Granger-causality tests and an EGARCH volatility analysis show that there is hardly any influence of trading activity driving metal spot prices in the long-term, but rather driving volatility to some extent. We find indications of price and volatility influencing effects of trading activity within sub-samples, such as phases of booms and crises. Contrary to public perception, commercial and long positions affect price levels and volatility far more than activities of non-commercial traders. However, for the reverse direction there is strong evidence that commodity prices and volatility drive trading positions.
\end{abstract}

\section{Keywords}

financialization, metal markets, commodity futures, CFTC, Granger-causality, EGARCH

\footnotetext{
*Acknowledgements: This paper has already been presented - among others — at the following conferences: The 31th Spring International Conference of the French Finance Association (AFFI) 2014, the 21st Annual Conference of the Multinational Finance Society (MFS) 2014, the World Finance Conference 2015 and the thematic Semester on Commodity Derivatives Markets at the University Paris Dauphine in 2015. Furthermore, the authors would like to thank Bahattin Büyükşahin, Delphine Lautier, Bertrand Villeneuve, Sébastien Ganneval, Hsiao-Chuan Wang, as well as our anonymous reviewers for their valuable comments and suggestions. Last but not least, we gratefully acknowledge partial support from the Bavarian Research Alliance (BayFOR) through the program "ForChange", supported by the Bavarian State Ministry of Education, Science and the Arts.
} 


\section{Introduction}

Over the past decade one can observe a remarkable increase in the popularity of commodity investing. These rapidly growing investments in commodity markets, which caused an enormous inflow of institutional funds into commodity futures markets, are often designated as "financialization". According to estimations from the U.S. Commodity Futures Trading Commission (CFTC) (CFTC, 2008), investment inflows to commodity futures indices increased from $\$ 13$ billion in 2003 to about $\$ 260$ billion by the middle of 2008. Due to coincidently occurring price increases and levels of volatility within major commodity markets, many market participants and policy-makers have ascribed this unusual behavior of commodity prices to commodity investing and particularly speculation. The issue is addressed by many scientific studies using the CFTC Commitments of Traders reports (COT), which in their aggregated form distinguish between at least two types of traders within the futures market: Commercial and noncommercial traders. Commercial traders primarily use commodity contracts to hedge themselves against price and volatility risks. These traders are for the most part companies, depending on the particular commodity. In contrast, non-commercial traders focus on investment opportunities within commodity markets without any hedging aspects (e.g. Szado, 2011). Such players are typically index funds- or investment managers, often defined as "speculators", who operate primarily in future markets by taking long-positions (Tang and Xiong, 2012), as they are not interested in any physical commodity delivery, but rather in achieving positive returns from these investments or to diversify their portfolio. Another consideration, and one which is occasionally overlooked in current discussion, is the fact that investments in commodity derivatives in general has risen sharply. Not only non-commercial investors are more active in these markets; commercial traders, such as commodity-producing and -processing companies as well as intermediaries, have increased their number of positions in the futures market to hedge against price and volatility risks in the spot market. However, commercial positions are often not considered in current literature, as related studies focus solely on non-commercial or index related positions (see Bohl, 2012; Gilbert, 2010a or Mayer, 2012).

The discussion about potential effects of financialization on commodity markets, which is comprehensively reviewed by Fattouh et al. (2013) for oil markets, raises the general question of the functioning 
and interaction of spot and futures markets. In the current discussion, it is often argued that financialization affects price building in physical spot markets along the following causal chain: Increased futures trading (particularly of financial investors) leads to changes in future prices, which in turn indirectly affect prices and volatility in underlying commodity spot markets. This causality is attributable to three potential channels (Cheng and Xiong, 2014). First, according to the theory of storage, spot and future prices are linked through a process of arbitrage, which involves simultaneous bugilbertying and selling of a metal in different markets - resulting in a risk-free transaction. The intensity and speed of this price adjustment is determined by interest rates, inventory costs, and the nature of storage itself. The second channel addresses the risk sharing mechanism in futures markets. Commodity producers, typically net short, are subject to strong hedging pressure (Keynes, 1923; Hicks, 1939), as there are usually fewer participants willing to take related long-positions. Therefore, a balanced risk premium for taking long positions exists, which directly links future and spot prices. Thirdly, following the theory of asymmetry of information within markets, future prices should react faster to new information serving as a signal for spot price development. Information imbalance between parties in future and spot markets is substantiated by the fact that futures markets show far less friction than spot markets (e.g. transaction costs). Thus, potentially better informed (speculative) traders in futures markets may accelerate the price discovery mechanism, which is accompanied by an increase in volatility; ergo, new information concerning fundamentals will be factored more rapidly (Harris, 1989). All three channels involve an impact on both direct prices and volatility. In addition, concerning volatility, Friedman (1953) postulates that increased participation of non-commercial traders generates further liquidity in the market, which in turn reduces volatility and enables market forces to correct irrational prices.

The frequently mentioned 'Masters Hypothesis' (e.g., Masters, 2008, 2009) in this context goes beyond the introduced mechanisms. Masters assigns massive buy-side demand originating from commodity index investments within future markets as major driver of physical spot price distortions. Moreover, this potential effect is often designated as a 'speculative bubble'. This line of argument, however, contradicts the assumption of a perfectly competitive market, in which no participant can directly influence the price of a product itself. 
However, there are potential alternatives for the actions of market participants, which could completely exhaust the introduced channels. For instance, if an increase in long demand leads to reduced insurance premiums, commercial hedgers may respond to these reduced premiums with increased hedging activity, resulting in no impact on cash prices themselves. The same applies to the channel of the theory of storage, in which an adjustment of the convenience yield without an adjustment of inventories seems possible. Concerning information asymmetry, the question is, whether and to what extent future market participants orientate towards prices and volatility of spot markets. Moreover, it is unclear whether the reaction of commercial traders dominates, as participants in spot markets are supposedly better informed. Lastly, potential effects on volatility could oppose each other, as in the case of 'momentum' traders, who boost highs and lows, thus generating increasing volatility.

To summarize, trading behavior - both speculation and hedging - may or may not influence price building in the spot market, cash prices, and volatility through the presented channels. Though intensively debated on a theoretical level, the topic of financialization's impacts in general still suffers from a lack of consensus of opinion. Currently, empirical investigations aim to shed more light on this issue.

Regarding soft commodities, especially the increasing prices for corn, soya, or wheat and the consequences for emerging nations have been analyzed by different authors and institutions (e.g. Gilbert, 2010a; Sanders and Irwin, 2010). Financialization in the market for energy commodities, like gas and oil, is important for a number of industries and, for instance, has been illuminated by Sanders et al. (2004). Another important group of commodities - metals - differs greatly in fundamental characteristics like suitability for storage, market conditions, or recyclability from other groups of commodities. This storability of metals can induce lower price volatility in general by buffering supply and demand shocks and enabling arbitrage opportunities. Smaller metal markets, for instance in comparison to energy markets, are generally considered suitable for financial investors. Although a large number of key current and future industries depend on these fundamental raw materials, to the best of our knowledge hardly any research on financialization and its implications in metal markets exists, except for some publications that selectively consider single or a small group of metals (see for instance Gilbert, 2010a or Mayer, 2012). Summarizing the above, recent studies reveal an ambiguity of results due to the use of 
different methods, varying time periods, and heterogeneous commodities. As a result, metal commodities lack sufficient investigation in this respect.

Therefore, this study is necessary because it investigates potential effects of financialization on the total set of CFTC metals, copper, gold, silver, platinum, and palladium, from an overall perspective by the lead-lag relationship between futures trading activity, actual spot prices, and volatility as well. We further contribute to existing literature by extending examination of financialization to the full and pure set of aggregated trading activity indicators of the CFTC, including commercials and non-commercials, which encompasses the longest available timeframe and both directions by the established framework of the Granger-causality analysis. Lastly, we extend the volatility examination by a supplemental EGARCH analysis.

The paper is structured as follows. Section 2 reviews the existing approaches identifying relationships among financialization, commodity prices, and volatility. Section 3 introduces design details and data of the Granger-causality test. Empirical results are presented in Section 4, followed by a discussion in Section 5, and a conclusion in the last section.

\section{Influence of financialization on commodity prices}

Different studies have tried to identify dependencies among financialization, commodity prices and volatility. Besides theoretical models, several recent articles apply empirical models to describe the impacts of financialization on commodity prices. Fattouh et al. (2013) identify six strands in empirical literature: The co-movement between commodity and stock prices, the influence of futures trading positions on future prices, the relationship between future and spot prices, the relationship between prices and inventories, the effect of supply and demand shocks, and the influences of time-varying risk premia. In this paper, we examine the relationship among futures trading positions and spot prices and volatility. Therefore, our study sheds light on the associations between two impacts of financialization on commodity prices: the strand concerning influence of futures trading positions on future prices, and the subsequent strand about the relationship between spot and future prices. To this end, we present in this section 
results of relevant studies, focusing on analysis of futures trading positions in the context of financialization, and stress publications providing evidence of those positions influencing future or spot prices and volatility.

A paper by Gilbert (2010a) - similar to many other studies - uses data of traders' positions, provided by the CFTC. Hence, within his study, Gilbert uses a Granger-causality analysis and identifies significant influences of index-based investment on commodity future prices within a dataset of different energy, agriculture, and metal commodities from 2006 to 2008. Gilbert's work is one of only a few studies regarding metals among other commodities. In a further study, he again uses Granger-causality tests and shows that increasing index-based investments in agricultural futures markets lead to rising agricultural prices from 2007 to 2008 (Gilbert, 2010b). Thereby he identifies further especially macroeconomic determinants of the price peak between 2007-2008, like growing GDP in China and the increasing demand for biofuels. Mayer (2012) uses non-aggregated COT report data from 2006 to 2009, which distinguishes between index traders, money managers, producers, and swap dealers. According to Mayer, futures trading positions - especially those of index traders and money managers - may influence the prices of some commodities. Robles et al. (2009) also use aggregated COT reports for agricultural futures and come to similar results.

Regarding effects on price volatility, Chatrath and Song (1999) identify a negative relationship between trading positions and spot price volatility. This is supported by Brunetti and Büyükşahin (2009), Brunetti et al. (2011) as well as partially by Irwin and Sanders (2010), who find evidence from CFTC data that increasing trading activity is not destabilizing, but rather reduces volatility, as it provides liquidity to the market. Using a GARCH methodology, Kim (2015) finds that increased trading volume reduces volatility levels of a number of examined commodities, and conversely does not influence price levels themselves. The analysis of increased financialization on price volatility also finds contrary causalities: Bessembinder and Seguin (1993) identify a positive correlation between trading volume and future price volatility. Yang et al. (2005) also examine the effects of trading positions on spot price volatility. Within their study for soft commodities, they find indications that an unexpected increase in futures trading causes increased volatility in the spot market. 
Conversely, other studies find less or no evidence for financialization as a driver of commodity prices or volatility. The research group of Scott H. Irwin and Dwight R. Sanders published a number of studies, which generally do not find evidence of trading positions causing price changes. Sanders et al. (2004) use CFTC data of energy commodities to test if these positions contain information about market returns. They find that changes in returns may influence positions of the non-commercial traders, but not the other way round. At least for commercial traders, they find some indication that positions lead to changes in commodity prices. In a further article, Irwin et al. (2009) analyze different CFTC trading positions and their impact on commodity prices. Again, they come to the conclusion that primarily, fundamentals drive commodity prices and that there is little evidence of speculative influences. Sanders and Irwin (2010) examine the correlations between CFTC positions and returns across different markets and discover that growing demand through financialization did not influence the returns in each market, thus weakening an argument supporting a theory on a recent bubble. Irwin and Sanders (2010) also analyze index fund investments within agricultural and energy markets, and find no relationship to commodity futures prices. In a further publication, Irwin and Sanders (2012a) do not find any indication of prices or volatility being influenced by index trading positions for agricultural markets. The latest study of Lehecka (2015), by examining a broad range of commodities, finds that hedging and speculative position behavior are not helpful in explaining prices. However, the author does not test for volatility. In the context of asset pricing, Mutafoglu et al. (2012) determine that price movements of gold, silver, and platinum cannot be forecast by analyzing traders' positions. They also find indication of the opposite: signs of feedback trading behavior.

Büyükşahin and Harris (2009) test if hedge funds or non-commercial traders cause price changes in the crude oil market. They were also not able to find any indication therefor. On the contrary, their results show that traders' positions follow price changes in commodity markets. Focusing on the effects on price volatility, Kocagil (1997) uses data from copper, gold, silver, and aluminum markets and rejects at least the hypothesis that financialization reduces spot price volatility. A study by Bryant, Bessler, and Haigh (2006) also does not show any indication for a significant causality between trading positions and spot price volatility in the gold market. Furthermore, in two recent publications, Bohl et al. (2012) and Bohl and Stephan (2013) are not able to show that index-trading positions may influence spot price 
volatility either positively or negatively. In a summarizing review, Irwin and Sanders (2012b) conclude that there is only small evidence in literature that structural changes in commodity futures markets cause rising commodity prices or higher volatility.

In Table 1, we sum up the most related empirical literature to give a brief overview on the used methodology, results, data and timeframe.

Table 1 - Overview of most related empirical literature on commodity financialization. Sorted alphabetically by authors' names.

\begin{tabular}{|c|c|c|c|c|c|c|}
\hline Name & Year & Commodity & $\begin{array}{l}\text { Time } \\
\text { frame }\end{array}$ & $\begin{array}{l}\text { Data source of trad- } \\
\text { ing activity }\end{array}$ & $\begin{array}{l}\text { Influ- } \\
\text { ence }^{1}\end{array}$ & Methodology \\
\hline $\begin{array}{l}\text { Bessembinder and } \\
\text { Seguin }\end{array}$ & 1993 & $\begin{array}{l}\text { Agricultures, } \\
\text { metals }\end{array}$ & $\begin{array}{l}1982- \\
1990\end{array}$ & $\begin{array}{l}\text { Columbia Business } \\
\text { School Futures Center, }\end{array}$ & Yes $(\mathrm{V})$ & Regression \\
\hline Bohl et al. & 2012 & Agricultures & $\begin{array}{l}2006- \\
2011\end{array}$ & CFTC & No $(V)$ & Regression \\
\hline Bohl and Stephan & 2013 & $\begin{array}{l}\text { Agricultures, en- } \\
\text { ergy }\end{array}$ & $\begin{array}{l}1992- \\
2012\end{array}$ & CFTC & No (V) & $\begin{array}{l}\text { Regression } \\
(\text { GARCH) }\end{array}$ \\
\hline $\begin{array}{l}\text { Brunetti and } \\
\text { Büyükşahin }\end{array}$ & 2009 & $\begin{array}{l}\text { Oil, gas, agricul- } \\
\text { tures }\end{array}$ & $\begin{array}{l}2005- \\
2009\end{array}$ & CFTC & $\begin{array}{l}\text { No }(\mathrm{P}) \\
\text { Yes }(\mathrm{V})\end{array}$ & Granger-causality \\
\hline $\begin{array}{l}\text { Brunetti, Büyükşa- } \\
\text { hin, and Harris }\end{array}$ & 2011 & $\begin{array}{l}\text { Oil, gas, agricul- } \\
\text { tures }\end{array}$ & $\begin{array}{l}2005- \\
2009\end{array}$ & CFTC & $\begin{array}{l}\text { No }(\mathrm{P}) \\
\text { Yes }(\mathrm{V})\end{array}$ & Granger-causality \\
\hline $\begin{array}{l}\text { Büyükşahin and } \\
\text { Harris }\end{array}$ & 2009 & Oil & $\begin{array}{l}2000- \\
2009\end{array}$ & CFTC & No $(P)$ & Granger-causality \\
\hline $\begin{array}{l}\text { Bryant, Bessler, and } \\
\text { Haigh }\end{array}$ & 2006 & Gold & $\begin{array}{l}1995- \\
2003\end{array}$ & CFTC & No $(\mathrm{V})$ & Causality analysis \\
\hline Chatrath and Song & 1999 & Agricultures & $\begin{array}{l}1983- \\
1995\end{array}$ & CFTC & Yes (V) & Regression \\
\hline Gilbert & $2010 \mathrm{a}$ & $\begin{array}{l}\text { Oil, metal, agri- } \\
\text { cultures }\end{array}$ & $\begin{array}{l}2006- \\
2008\end{array}$ & CFTC & Yes (P) & Granger-causality \\
\hline Gilbert & $2010 b$ & Agricultures & $\begin{array}{l}2006- \\
2008\end{array}$ & CFTC & Yes $(\mathrm{P})$ & Granger-causality \\
\hline Irwin and Sanders & 2010 & Agricultures, gas & $\begin{array}{l}2006- \\
2009\end{array}$ & CFTC & $\begin{array}{l}\text { No }(\mathrm{P}) \\
\text { Yes }(\mathrm{V})\end{array}$ & Granger-causality \\
\hline Irwin and Sanders & $2012 \mathrm{a}$ & Oil, gas & $\begin{array}{l}2007- \\
2011\end{array}$ & CFTC & $\begin{array}{l}\text { No }(\mathrm{P}) \\
\text { No }(\mathrm{V})\end{array}$ & Granger-causality \\
\hline Irwin et al. & 2009 & Oil & $\begin{array}{l}1995- \\
2006\end{array}$ & CFTC & No $(P)$ & Granger-causality \\
\hline Kocagil & 1997 & Metals & $\begin{array}{l}1980- \\
1990\end{array}$ & Simulation & No $(\mathrm{V})$ & $\begin{array}{l}\text { Monte Carlo Simu- } \\
\text { lation \& Regres- }\end{array}$ \\
\hline Kim & 2015 & $\begin{array}{l}\text { Energy, agricul- } \\
\text { tures, metals }\end{array}$ & $\begin{array}{l}1992- \\
2012\end{array}$ & CFTC & $\begin{array}{l}\text { Yes }(\mathrm{V}) \\
\text { No }(\mathrm{P})\end{array}$ & $\begin{array}{l}\text { Regression } \\
(\text { GARCH) }\end{array}$ \\
\hline Lehecka & 2015 & $\begin{array}{l}\text { Energy, agricul- } \\
\text { tures, metals }\end{array}$ & $\begin{array}{l}1995- \\
2013\end{array}$ & CFTC & No $(\mathrm{P})$ & Granger-causality \\
\hline Mayer & 2012 & $\begin{array}{l}\text { Oil, metals, agri- } \\
\text { cultures }\end{array}$ & $\begin{array}{l}2006- \\
2009\end{array}$ & CFTC & Yes (P) & Granger-causality \\
\hline Mutafoglu et al. & 2012 & Metals & $\begin{array}{l}1993- \\
2009\end{array}$ & CFTC & No $(P)$ & Granger-causality \\
\hline
\end{tabular}




\begin{tabular}{|l|l|l|l|l|l|l|}
\hline Robles et al. & 2009 & Agricultures & $\begin{array}{l}2002- \\
2008\end{array}$ & CFTC & Yes (P) & Granger-causality \\
\hline Sanders and Irwin & 2010 & Agricultures & $\begin{array}{l}2006- \\
2008\end{array}$ & CFTC & No (P) & Regression analysis \\
\hline Sanders et al. & 2004 & Oil, gas & $\begin{array}{l}1992- \\
1999\end{array}$ & CFTC & No (P) & Granger-causality \\
\hline Yang et al. & 2005 & Agricultures & $\begin{array}{l}1992- \\
2001\end{array}$ & Datastream & Yes (V) & Granger-causality \\
\hline
\end{tabular}

Note: ${ }^{1}$ Speculative Influence means that the regarded study significantly identified financialization influencing commodity prices $(\mathrm{P})$ or commodity volatility $(\mathrm{V})$.

Through our review of recent articles, we can see that the results are quite distinct: Some publications find evidence for trading positions influencing prices or volatility. They hypothesize that the latter can be influenced positively (financialization is destabilizing and leads to increasing volatility) or negatively (financialization is stabilizing and leads to decreasing volatility). Other studies reject those hypotheses, as no significant influence of trading positions either on prices or on volatility is found. Some, but not all of them test the reverse causality (changes in prices or volatility cause changes in trading positions) as well, which may lead to complete results.

All in all, the number of studies supporting the hypothesis that financialization may influence prices and volatility is similar to the amount of studies rejecting this assumption. The reasons for these results of course may be diverse: We can state that most of the authors use the COT dataset. Furthermore, the Granger-causality test is the most common methodology for testing coherences between commodity prices and traders' positions. But there are obvious differences between the studies: For instance, different timeframes, commodities, trading positions, aggregates, or definitions are used. Thus, from current literature it is not possible to clearly answer the question, if increased trading through financialization does influence commodity prices or volatility in general.

As described in section 1, it is important to know, especially for metal markets and dependent industries, if developments in futures markets may influence spot prices. Concluding this literature review, we can observe that there is no long-term causality study of metal futures trading on spot prices and spot price volatility. Hence, we contribute to the existing literature by extending the examination of financialization on the full set of CFTC metals and for the longest available weekly timeframe. For this purpose, we use a unique and widespread data sample of 21 years, from January 1993 to December 2013, which 
we analyze as a whole as well as in separated sub-samples. To avoid potentially biased results, we employ the pure trading positions of the CFTC COT dataset. Furthermore, we conduct a two-sided Granger-causality analysis with optimized lag length to discover possible causalities in both directions. Third, we analyze the effects on original spot prices, which are of special interest for dependent industries. Lastly, we also analyze both causalities between trading positions and spot prices, as well as volatility for both commercial and non-commercial traders.

\section{Methodology}

In order to examine the role of financialization of metal markets in the behavior of prices and volatility, we use - as in a large part of related studies - the common and suitable methodological framework of the Granger-causality (Granger, 1969). Moreover, regarding the volatility analysis, we calculate a supplemental EGARCH model. First, we take a closer look at utilized data and processing.

\section{Data and Processing}

The analysis includes five major metals: copper, gold, palladium, platinum, and silver. This selection represents the full range of pure metals traded on the New York Mercantile Exchange (NYMEX), monitored by the CFTC. This selection consists of four precious metals and copper as the most important representative of industrial metals. The CFTC provides two types of COT data: Aggregated COT reports (since 1986) and disaggregated COT reports (since 2006). After a long-term study, the aggregated COT reports are the subject of this empirical analysis. Based on these reports, we use the entire set of individual trading factors, representing hedging as well as speculative activity. Therefore, following Büyükşahin and Harris (2009), we use pure CFTC data including eight absolute trading factors: open interest, number of traders, and their respective positions (total reportable, commercial and non-commercial, each long and short). Table 2 gives a brief overview of the used variables and shortcuts. 
Table 2 - Overview of analyzed trading positions - absolute measures

\begin{tabular}{|c|c|c|c|c|c|c|c|}
\hline \multicolumn{8}{|c|}{ absolute measures } \\
\hline $\begin{array}{c}\text { open inter- } \\
\text { est }\end{array}$ & $\begin{array}{c}\text { number of } \\
\text { traders }\end{array}$ & $\begin{array}{l}\text { total re- } \\
\text { portable } \\
\text { positions- } \\
\text { long }\end{array}$ & $\begin{array}{l}\text { total re- } \\
\text { portable } \\
\text { positions- } \\
\text { short }\end{array}$ & $\begin{array}{c}\text { commercial } \\
\text { positions- } \\
\text { long }\end{array}$ & $\begin{array}{l}\text { commercial } \\
\text { positions- } \\
\text { short }\end{array}$ & $\begin{array}{l}\text { non-com- } \\
\text { mercial po- } \\
\text { sitions-long }\end{array}$ & $\begin{array}{c}\text { non-com- } \\
\text { mercial po- } \\
\text { sitions- } \\
\text { short }\end{array}$ \\
\hline (OI) & (NT) & (TRL) & (TRS) & (CL) & $(\mathrm{CS})$ & (NCL) & (NCS) \\
\hline
\end{tabular}

Actual underlying true spot prices originate from Thomson Reuters Datastream. Additionally, as we analyze the influence of trading activity on volatility of the commodity prices, we calculate the weekly volatility from the daily price time series. The complete data set in our analysis, including metal prices, volatility and trading positions, covers the CFTC's longest available timeframe from January 1993 to December 2013, and includes 1095 observations for each time series in a weekly frequency ${ }^{1}$.

With respect to minor data gaps and requirements of the Granger-causality and the relating autoregressive models, some data adjustments and preprocessing are necessary. To ensure covariance stationarity, homoscedasticity, and scale invariance, the relative change of each variable against the previous week is calculated. Consequently, in all test cases we use returns to conduct the empirical analysis. Additionally, the augmented Dickey-Fuller test (ADF test) is applied to prove covariance stationarity of each time series. To deal with missing values, we substitute the respective value with one from the previous day. All in all, 13 missing values out of 49,320 cells were substituted.

\section{Granger-causality}

In the following analysis, the traditional concept of Granger-causality is applied to assess potential causalities and impact of the selected indicators for trading activity on the volatility and spot price movements of metals, and vice versa. In other words, it is noteworthy if changes in positions, hence trading activity, can influence price movements and thus indicate market inefficiencies, and conversely, if traders and their respective positions follow changes in price and volatility. Consequently, e.g. following Hamilton (1994) or Sanders et al. (2004), all relationships are tested in both directions examining the lead-lag relationship between two series. The used proxies refer to transactions in futures markets, as

\footnotetext{
${ }^{1}$ For palladium, trading positions data between August 2000 to September 2004 is not available or is only very limited.
} 
described in detail in the previous section. The related null hypotheses are that each proxy for trading activity $X^{F}$ does not Granger-cause metal spot return or volatility $R^{S, V}\left(\theta_{j}=0\right.$ for all $\left.j\right)$ and vice versa. Accordingly, the following unrestricted equations were estimated:

$$
\begin{gathered}
R_{t}^{S, V}=\phi+\sum_{i=1}^{m} \lambda_{i} R_{t-i}^{S, V}+\sum_{j=1}^{n} \theta_{j} X_{t-j}^{F}+\varepsilon_{t} \\
X_{t}^{F}=\phi+\sum_{i=1}^{m} \lambda_{i} X_{t-i}^{F}+\sum_{j=1}^{n} \theta_{j} R_{t-j}^{S, V}+\varepsilon_{t}
\end{gathered}
$$

where $R_{t}^{S, V}$ is the weekly logarithmic return of either spot price $S$ or volatility $V$. The latter is calculated by the standard deviation of the previous five trading days. Analogously, the variable $X_{t}^{F}$ denotes the logarithmic weekly change in the respective proxy for futures trading activity $F$, where $F \in\{\mathrm{OI}, \mathrm{NT}, \mathrm{TRL}, \mathrm{TRS}, \mathrm{CL}, \mathrm{CS}, \mathrm{NCL}, \mathrm{NCS}\}$. By the use of logarithmic returns, stationarity can be guaranteed. $\phi$ is the intercept and $\varepsilon_{t}$ is an error term. Both equations (1) and (2) in the following are reduced by the exogenous explanatory variable to obtain the restricted model of each combination. Hence, in the restricted model, it is assumed that the dependent variable $R_{t}^{S, V}$ in (1) and $X_{t}^{F}$ in (2) is determined only by its own lag values. The residual sum of squares of both models, restricted and unrestricted, are then compared using an F-test to reject the respective null hypothesis: An additional explanatory variable of the unrestricted model has no influence. To determine the most appropriate lag-structure $(m, n)$ for each model, we use the Akaike information criterion (Beveridge and Oickle, 1994) for the specific commodity and variable combination. Here, according to Sanders et al. (2004) the lag-structure is determined by a minimum lag of one week and a maximum lag of twelve weeks.

To analyze the relationships between trading positions and volatility from a different perspective, we conduct an EGARCH analysis for the full time frame. We therefore test if the trading positions determine the estimated EGARCH volatility. Using an EGARCH methodology is a suitable approach when analysing commodity prices volatility, see Guida and Matringe (2004). To test relationships in a multivariate EGARCH model, it is necessary to reduce our sample of absolute trading factors, as there is multicollinearity between some of the examined trading measures. For instance, the sum of TRL and TRS (plus few non-reportable positions) almost equals OI. Thus, within this additional analysis, we test 
for a significant relationship between OI, NT, NCL, NCS, TRL, and EGARCH-volatility. In accordance with the application of Granger-causality tests, we examine lagged relationships between trading activity and volatility, and therefore include trading activity variables with a time lag of one week.

Hence, according to Brownlees et al. (2012), we use the following equations for our two-stage-analysis

$$
y_{t}=\mu+\varepsilon_{t} \text { where } \varepsilon_{t}=\sigma_{t} z_{t}
$$

$$
\log \sigma_{t}^{2}=\kappa+\beta_{1}\left(O I_{t-1}\right)+\beta_{2}\left(N T_{t-1}\right)+\beta_{3}\left(N C L_{t-1}\right)+\beta_{4}\left(N C S_{t-1}\right)+\beta_{5}\left(T R L_{t-1}\right)+
$$

$$
\sum_{i=1}^{P} \gamma_{i} \log \sigma_{t-i}^{2}+\sum_{j=1}^{Q} \alpha_{j}\left[\frac{\left|\varepsilon_{t-j}\right|}{\sigma_{t-j}}-E\left\{\frac{\left|\varepsilon_{t-j}\right|}{\sigma_{t-j}}\right\}\right]+\sum_{j=1}^{Q} \xi_{j}\left(\frac{\varepsilon_{t-j}}{\sigma_{t-j}}\right)
$$

where $\gamma_{i}$ are the GARCH parameters, $\xi_{j}$ denote the $\mathrm{ARCH}$ parameters, and $\alpha_{j}$ are the asymmetric or leverage parameters. The respective lag-structure $(P, Q)$ for the GARCH and ARCH terms is calculated with an out-of-sample procedure.

Granger-causality tests as well as EGARCH analyses were calculated for each of the five metals, copper, gold, palladium, platinum, and silver. These analyses are done for the full period from 1993 to 2013. In order to capture potential changes in traders' categories (e.g. index fund traders show up later within commercials) and possible short-term effects - as correlation between trading activity and price changes may be stronger in some periods (e.g. crisis or booms) than in others - we secondly split our data sample into seven 3-years sub-samples and conduct the Granger-causality test for each sub-period by following Gilbert (2010b). Results are presented in the following.

\section{Results}

A complete overview of the results of the full time period, including p-values from the F-tests of the bidirectional Granger-causality tests, can be found in tables 5a, 5b (spot) and 6a, 6b (volatility). Tables $7 \mathrm{a}, 7 \mathrm{~b}$ and $8 \mathrm{a}, 8 \mathrm{~b}$ show respective results for the 3 -year sub periods.

Regarding results of the spot price analysis, the overall results for the full time frame show that the spot price (SP) of metals with 16 out of 40 significant cases drives trading positions (TP) quite strongly 
$(\mathrm{TP} \leftarrow \mathrm{SP})$. In this case we measure the most and strongest correlation in the overall analysis; however, in general there is less contrast between commercial and non-commercial traders. This result could characterize a trend following behavior of a wide range of producers and investors. Regarding results for the specific commodities in more detail, positions of traders with exposure in copper with 6 out of 8 significant factors are especially strongly influenced by price development. Gold and platinum positions, however, are driven by previous changes in spot prices in only 1 (Gold) and 2 (Platinum) cases. The opposite direction, which tests for Granger-causality of positions on spot prices (SP $\leftarrow \mathrm{TP})$, shows significant impact for the overall period in only 4 out of 40 cases, which is only 10\%. 3 significant causalities are assigned to commercial positions, which are only partially attributed to speculative trading. Accordingly, spot prices of silver, copper, and platinum are not at all driven by trading activity. For palladium, however, we observe a slightly different picture. Spot price returns are significantly influenced in 3 cases, all related to commercial positions. This could be an indication that within palladium markets, producer and merchants seem to be better informed or are able to influence spot price returns by their trading behavior.

When regarding results of spot prices as an independent variable $(\mathrm{TP} \leftarrow \mathrm{SP})$ for the 3-year-sub-periods from 1993 to 2013, we find less structure. Nevertheless, with 54 out of 264 significant results this direction generally shows sound causality. Copper positions, consistent with results of the full time frame, seem to be most influenced by price movements, as seen in 17 cases. Thus, copper trading activities react obviously more strongly to price changes than trading of other metals. This seems to be of special interest, as copper is the only pure industrial metal within our sample.

Taking a closer look at the detailed results for the reverse direction (SP $\leftarrow \mathrm{TP})$, we again find less evidence for trading activity influencing spot prices. 27 test results show significance, which is only $10.2 \%$ of all values. However, we observe 14 significant causalities within the sub-period from January 2008 to December 2010, the period of the world financial crisis. Notably, this is more than half of the total. Furthermore, palladium and platinum prices seem to be more vulnerable, as these two metals make up $52 \%$ of the significant results in this direction. This finding is also consistent with that of the full frame. 
However, the volatility analysis shows a more balanced relation. Regarding the full time frame, we observe a variety of significant tests for both directions. Volatility (VO) is Granger-causing $27.5 \%$ (11 out of 40) of all trading indicators (TP $\leftarrow \mathrm{VO}$ ), which is overall considerably less than spot price changes cause. Also, the overall results for volatility show less difference between commercial and non-commercial positions. Thus, for all future market participants, price changes seem to be more decisive concerning trading behavior than volatility. Nevertheless, when regarding specific metals, volatility significantly influences 6 out of 8 copper positions, but none for silver and palladium within the full time frame. The other way round (VO $\leftarrow \mathrm{TP})$, none of the palladium positions cause changes in volatility, but 5 out of 8 silver positions and 4 out of 8 gold and copper positions drive volatility significantly. Within this direction (VOடTP), we find $14(35 \%)$ significant values in total, which is a remarkable result compared to the spot price analysis. Thus, volatility is much more vulnerable to changes in traders' positions than prices are.

When results of the seven subsamples are compared, we again find proof of a more balanced relationship. For volatility causing changes in positions $(\mathrm{TP} \leftarrow \mathrm{VO})$, we find 40 out of 264 significant values, which with $15 \%$ is less than within the overall period. The reduced significance is thereby assumed to be a statistical effect due to smaller sample size within the sub-samples. Consistent with results of the full time frame, we find that 27 of those 40 significant position changes are caused by volatility of the precious metals, gold and silver. Further in this regard, we find 10 of these significant cases in the period from 1999-2001, and 9 in 2005-2007, both pre-crises periods. In both subsequent periods, however, there are only 2 (2002-2004) and 3 (2008-2010) significant values. This is interesting, as there seems to be a peak period for each just before a crisis. So, regarding volatility's influence on trading behavior within our sub-sample analysis, we observe stronger effects in pre-crisis phases and little to no evidence within periods of crisis.

The reverse direction (VO $\leftarrow \mathrm{TP})$ for all sub-samples shows 29 significant values. Here, we observe a heterogeneous picture through our sample periods. Considering specific trading positions, there are 14 significant causalities for long positions, and solely 7 for short. One can then assume that long positions, 
and thus index investors, have slightly greater influence on volatility than others. This may be an indication of the role of futures market trading activity in the price discovery process, as we observe less causality of trading positions on direct price changes.

Tables 3 - Overview of the results of bidirectional Granger-causality tests for the overall period - Spot price and absolute measures

\section{3a - Spot price as independent variable $(\mathrm{TP} \leftarrow \mathrm{SP})$}

\begin{tabular}{cllllllllll}
\hline Period & Com. & OI $^{\mathbf{a}}$ & NT & TRL & TRS & CL & CS & NCL & \multicolumn{2}{l}{ NCS } \\
\hline & $\mathrm{Ag}^{\mathrm{b}}$ & 0.317 & $0.017^{*}$ & 0.130 & 0.130 & 0.123 & $0.001^{* * *}$ & $0.007^{* *}$ & $0.002^{* *}$ & $\mathbf{4}$ \\
Jan 93- & $\mathrm{Au}$ & 0.194 & 0.431 & 0.109 & 0.114 & $0.015^{*}$ & 0.121 & 0.095 & 0.143 & $\mathbf{1}$ \\
Dec 13 & $\mathrm{Co}$ & $0.020^{*}$ & $0.010^{*}$ & 0.105 & $0.002^{* *}$ & 0.113 & $0.000^{* * *}$ & $0.000^{* * *}$ & $0.012^{*}$ & $\mathbf{6}$ \\
& $\mathrm{Pd}^{\mathrm{c}}$ & 0.064 & 0.150 & $0.035^{*}$ & 0.110 & 0.236 & $0.019^{*}$ & $0.001^{* * *}$ & 0.318 & $\mathbf{3}$ \\
& $\mathrm{Pl}$ & 0.269 & $0.009^{* *}$ & 0.110 & 0.121 & $0.013^{*}$ & 0.163 & 0.610 & 0.515 & $\mathbf{2}$ \\
\hline \# of significant values $<0.05$ & $\mathbf{1}$ & $\mathbf{3}$ & $\mathbf{1}$ & $\mathbf{1}$ & $\mathbf{2}$ & $\mathbf{3}$ & $\mathbf{3}$ & $\mathbf{2}$ & $\mathbf{1 6}$
\end{tabular}

\section{$3 \mathrm{~b}$ - Spot price as dependent variable $(\mathrm{SP} \leftarrow \mathrm{TP})$}

\begin{tabular}{|c|c|c|c|c|c|c|c|c|c|c|}
\hline Period & Com. & $\mathrm{OI}^{\mathrm{a}}$ & NT & TRL & TRS & $\overline{C L}$ & $\mathrm{CS}$ & NCL & NCS & \\
\hline \multirow{5}{*}{$\begin{array}{l}\text { Jan 93- } \\
\text { Dec } 13\end{array}$} & $\mathrm{Ag}^{\mathrm{b}}$ & 0.116 & 0.909 & 0.384 & 0.368 & 0.939 & 0.674 & 0.263 & 0.965 & $\mathbf{0}$ \\
\hline & $\mathrm{Au}$ & 0.458 & 0.485 & 0.652 & 0.369 & $0.040 *$ & 0.916 & 0.962 & 0.660 & 1 \\
\hline & Co & 0.905 & 0.836 & 0.547 & 0.969 & 0.148 & 0.208 & 0.889 & 0.494 & $\mathbf{0}$ \\
\hline & $\mathrm{Pd}^{\mathrm{c}}$ & 0.059 & 0.447 & 0.053 & $0.006^{* *}$ & $0.009^{* *}$ & $0.002 * *$ & 0.256 & 0.419 & 3 \\
\hline & $\mathrm{Pl}$ & 0.464 & 0.744 & 0.377 & 0.492 & 0.061 & 0.750 & 0.701 & 0.904 & $\mathbf{0}$ \\
\hline$\#$ of & jes & $\mathbf{0}$ & 0 & 0 & 1 & 2 & 1 & $\mathbf{0}$ & $\mathbf{0}$ & 4 \\
\hline
\end{tabular}

Note:

${ }^{a}$ A detailed description and abbreviations of corresponding indicators for trading activity can be found in table 2

Estimating both directions of spot and trading activity relation, $4 a$ classifies the model: $X_{t}^{F}=\phi+\sum_{i=1}^{m} \lambda_{i} X_{t-i}^{F}+\sum_{i=1}^{n} \theta_{j} R_{t-i}^{S, V}+\varepsilon_{t}$ and, hence, $4 b$ the other direction: $R_{t}^{S, V}=$ $\phi+\sum_{i=1}^{m} \lambda_{i} R_{t-i}^{S, V}+\sum_{i=1}^{n} \theta_{j} X_{t-i}^{F}+\varepsilon_{t}$. The related lag-structure $(m, n)$ for each model is determined individually by the Akaike information criterion. The displayed $p$-values are from the F-tests of the null hypothesis $\theta_{j}=0 \forall F$ or $S, V$.

${ }^{b}$ The chemical symbols behind the abbreviation for the examined metals are as follows: Copper $(\mathrm{Cu})$, gold $(\mathrm{Au})$, palladium (Pd), platinum (Pt), and silver (Ag). Significant values are highlighted: $(*)$ denotes the $5 \%,(* *)$ the $1 \%$, and $(* * *)$ the $0.1 \%$ level.

${ }^{c}$ For palladium, no data is available from August 2000 to September 2002. Therefore, the results for palladium for the full period are from September 2002 to December 2013 
Tables 4 - Overview of the results of bidirectional Granger-causality tests for the overall period - Volatility and absolute measures

$4 \mathrm{a}$ - Volatility as independent variable $(\mathrm{TP} \leftarrow \mathrm{VO})$

\begin{tabular}{|c|c|c|c|c|c|c|c|c|c|c|}
\hline Period & Com. & $\mathrm{OI}^{\mathbf{a}}$ & NT & TRL & TRS & $\mathbf{C L}$ & $\mathrm{CS}$ & NCL & NCS & \\
\hline \multirow{5}{*}{$\begin{array}{l}\text { Jan 93- } \\
\text { Dec } 13\end{array}$} & $\mathrm{Ag}^{\mathrm{b}}$ & 0.569 & 0.633 & 0.368 & 0.317 & 0.399 & 0.850 & 0.073 & 0.390 & $\overline{0}$ \\
\hline & $\mathrm{Au}$ & 0.648 & $0.000^{* * *}$ & 0.914 & 0.606 & 0.073 & 0.138 & $0.026^{*}$ & 0.162 & 2 \\
\hline & Co & $0.027 *$ & $0.000 * * *$ & $0.001 * * *$ & $0.001 * *$ & $0.011^{*}$ & 0.227 & 0.101 & $0.001 * * *$ & 6 \\
\hline & $\mathrm{Pd}^{\mathrm{c}}$ & 0.601 & 0.903 & 0.623 & 0.557 & 0.852 & 0.832 & 0.394 & 0.796 & 0 \\
\hline & $\mathrm{Pl}$ & $0.015^{*}$ & $0.035^{*}$ & $0.022 *$ & 0.065 & 0.551 & 0.135 & 0.327 & 0.355 & 3 \\
\hline \# of significa & des $<0$ & 2 & 3 & 2 & 1 & 1 & $\mathbf{0}$ & 1 & 1 & 11 \\
\hline
\end{tabular}

4b - Volatility as dependent variable $(\mathrm{VO} \leftarrow \mathrm{TP})$

\begin{tabular}{rllllllllll}
\hline Period & Com. & OI $^{\mathrm{a}}$ & NT & TRL & TRS & CL & CS & NCL & NCS \\
\hline & $\mathrm{Ag}^{\mathrm{b}}$ & 0.089 & $0.040^{*}$ & 0.088 & $0.014^{*}$ & $0.030^{*}$ & $0.001^{* *}$ & $0.016^{*}$ & 0.163 & $\mathbf{5}$ \\
$\operatorname{Jan} 93-$ & $\mathrm{Au}$ & $0.006^{* *}$ & 0.074 & 0.072 & $0.002^{* *}$ & 0.313 & $0.000^{* * *} 0.000^{* * *} 0.524$ & $\mathbf{4}$ \\
$\operatorname{Dec} 13$ & $\mathrm{Co}$ & $0.048^{*}$ & $0.007^{* *}$ & $0.043^{*}$ & 0.066 & 0.209 & 0.299 & 0.129 & $0.000^{* * *}$ & $\mathbf{4}$ \\
& $\mathrm{Pd}^{\mathrm{c}}$ & 0.292 & 0.197 & 0.358 & 0.607 & 0.907 & 0.356 & 0.189 & 0.377 & $\mathbf{0}$ \\
& $\mathrm{Pl}$ & 0.350 & 0.625 & 0.177 & 0.173 & 0.530 & $0.037^{*}$ & 0.356 & 0.107 & $\mathbf{1}$ \\
\hline \# of significant values $<0.05$ & $\mathbf{2}$ & $\mathbf{2}$ & $\mathbf{1}$ & $\mathbf{2}$ & $\mathbf{1}$ & $\mathbf{3}$ & $\mathbf{2}$ & $\mathbf{1}$ & $\mathbf{1 4}$
\end{tabular}

Note:

${ }^{\mathrm{N}}$ A detailed description and abbreviations of corresponding indicators for trading activity can be found in table 2 .

Estimating both directions of spot and trading activity relation, $5 a$ classifies the model: $X_{t}^{F}=\phi+\sum_{i=1}^{m} \lambda_{i} X_{t-i}^{F}+\sum_{i=1}^{n} \theta_{j} R_{t-i}^{S, V}+\varepsilon_{t}$ and, hence, $5 b$ the other direction: $R_{t}^{S, V}=$ $\phi+\sum_{i=1}^{m} \lambda_{i} R_{t-i}^{S, V}+\sum_{i=1}^{n} \theta_{j} X_{t-i}^{F}+\varepsilon_{t}$. The related lag-structure $(m, n)$ for each model is determined individually by the Akaike information criterion. The displayed $p$-values are from the F-tests of the null hypothesis $\theta_{j}=0 \forall F$ or $S, V$. Volatility $\mathrm{V}$ is calculated by the standard deviation from the previous five trading days.

${ }^{\mathrm{b}}$ The chemical symbols behind the abbreviation for the examined metals are as follows: Copper $(\mathrm{Cu})$, gold $(\mathrm{Au})$, palladium $(\mathrm{Pd})$, platinum $(\mathrm{Pt})$, and silver $(\mathrm{Ag})$. Significant values are highlighted $(*)$ denotes the $5 \%,(* *)$ the $1 \%$ and $(* * *)$ the $0.1 \%$ level.

${ }^{c}$ For palladium, no data is available from August 2000 to September 2002. Therefore, the results for palladium for the full period are from September 2002 to December 2013. 
Tables 5 -- Overview of the results of bidirectional Granger-causality tests for subperiods - Spot price and absolute measures

5 a - Spot price as independent variable $(\mathrm{TP} \leftarrow \mathrm{SP})$

\begin{tabular}{|c|c|c|c|c|c|c|c|c|c|c|}
\hline Period & Com. & $\mathrm{OI}^{\mathbf{a}}$ & NT & TRL & TRS & $\mathbf{C L}$ & $\mathrm{CS}$ & NCL & NCS & \\
\hline \multirow{5}{*}{$\begin{array}{l}\text { Jan } 93- \\
\text { Dec } 95\end{array}$} & $\mathrm{Ag}^{\mathrm{b}}$ & 0.394 & 0.130 & 0.734 & 0.422 & 0.514 & 0.432 & $0.048^{*}$ & 0.526 & 1 \\
\hline & $\mathrm{Au}$ & 0.610 & 0.203 & 0.476 & 0.668 & 0.684 & 0.813 & 0.769 & 0.618 & $\mathbf{0}$ \\
\hline & Co & 0.241 & 0.365 & 0.249 & 0.447 & $0.019^{*}$ & 0.527 & $0.007 * *$ & 0.084 & 2 \\
\hline & $\mathrm{Pd}^{\mathrm{c}}$ & 0.095 & 0.484 & $0.041^{*}$ & 0.153 & 0.569 & 0.064 & 0.059 & 0.479 & 1 \\
\hline & $\mathrm{Pl}$ & 0.510 & 0.302 & 0.634 & 0.629 & 0.980 & 0.479 & 0.877 & 0.654 & $\mathbf{0}$ \\
\hline \multirow{3}{*}{\multicolumn{2}{|c|}{ Jan 96- Dec 98Co }} & 0.928 & 0.942 & 0.730 & 0.790 & 0.216 & 0.231 & 0.087 & 0.310 & 0 \\
\hline & & $0.017^{*}$ & 0.177 & 0.664 & $0.044 *$ & 0.472 & 0.721 & 0.427 & 0.483 & 2 \\
\hline & & 0.238 & 0.674 & 0.724 & 0.634 & $0.019^{*}$ & 0.336 & 0.070 & $0.000 * * *$ & 2 \\
\hline & $\mathrm{Pd}$ & 0.370 & $0.036^{*}$ & 0.624 & 0.589 & $0.020^{*}$ & 0.673 & 0.759 & 0.597 & 2 \\
\hline & $\mathrm{Pl}$ & 0.260 & 0.150 & 0.328 & 0.415 & $0.003 * *$ & 0.956 & 0.079 & 0.195 & 1 \\
\hline \multirow{3}{*}{\multicolumn{2}{|c|}{ Jan 99-Dec 01 Co }} & 0.566 & $0.022^{*}$ & 0.531 & 0.489 & $0.020^{*}$ & $0.000 * * *$ & $0.049^{*}$ & $0.001 * * *$ & 5 \\
\hline & & 0.889 & $0.000 * * *$ & 0.742 & 0.682 & 0.734 & 0.130 & 0.293 & 0.271 & 1 \\
\hline & & 0.454 & 0.937 & 0.414 & 0.482 & $0.001 * * *$ & $0.004 * *$ & $0.001 * * *$ & 0.077 & 3 \\
\hline & $\mathrm{Pd}$ & / & / & / & / & / & / & / & / & l \\
\hline & $\mathrm{Pl}$ & 0.770 & 0.269 & 0.873 & 0.921 & 0.822 & 0.330 & 0.792 & 0.834 & $\mathbf{0}$ \\
\hline \multirow{3}{*}{\multicolumn{2}{|c|}{ Jan 02-Dec 04 Co }} & $0.025^{*}$ & 0.552 & $0.022^{*}$ & $0.048^{*}$ & 0.370 & $0.017^{*}$ & $0.034^{*}$ & $0.000 * * *$ & 6 \\
\hline & & 0.778 & 0.553 & 0.357 & 0.765 & $0.047 *$ & 0.580 & 0.208 & 0.965 & 1 \\
\hline & & $0.010 * *$ & 0.809 & 0.727 & $0.020 *$ & 0.343 & 0.296 & 0.167 & 0.140 & 2 \\
\hline & $\mathrm{Pd}$ & / & / & 1 & / & / & / & / & / & l \\
\hline & $\mathrm{Pl}$ & 0.207 & $0.006^{* *}$ & 0.186 & 0.399 & $0.002 * *$ & 0.733 & $0.044 *$ & 0.117 & 3 \\
\hline \multirow{3}{*}{\multicolumn{2}{|c|}{ Jan 05-Dec 07 Co }} & 0.240 & 0.384 & 0.443 & 0.575 & 0.637 & 0.793 & 0.900 & 0.326 & $\mathbf{0}$ \\
\hline & & 0.089 & $0.016^{*}$ & 0.087 & 0.162 & 0.634 & 0.505 & 0.405 & 0.923 & 1 \\
\hline & & 0.383 & 0.794 & 0.645 & 0.635 & 0.410 & 0.703 & 0.382 & 0.074 & $\mathbf{0}$ \\
\hline & $\mathrm{Pd}$ & 0.054 & $0.001 * *$ & $0.026^{*}$ & $0.011^{*}$ & $0.036^{*}$ & $0.005 * *$ & 0.230 & 0.992 & 5 \\
\hline & $\mathrm{Pl}$ & 0.679 & 0.589 & 0.942 & 0.180 & 0.369 & 0.795 & 0.184 & 0.786 & $\mathbf{0}$ \\
\hline \multirow{3}{*}{\multicolumn{2}{|c|}{ Jan 08-Dec 10 Co }} & 0.140 & $0.013^{*}$ & 0.116 & 0.099 & 0.952 & $0.006^{* *}$ & 0.255 & 0.653 & 2 \\
\hline & & 0.697 & 0.223 & 0.834 & 0.438 & $0.002 * *$ & 0.790 & 0.724 & 0.073 & 1 \\
\hline & & $0.005 * *$ & $0.000 * * *$ & $0.021 *$ & $0.022 *$ & 0.165 & $0.025^{*}$ & 0.774 & 0.507 & 5 \\
\hline \multicolumn{2}{|c|}{$P d$} & 0.763 & 0.768 & 0.765 & 0.775 & 0.086 & 0.739 & 0.217 & 0.387 & $\mathbf{0}$ \\
\hline & $\mathrm{Pl}$ & 0.095 & 0.178 & 0.060 & 0.209 & 0.709 & 0.369 & 0.060 & 0.067 & $\mathbf{0}$ \\
\hline \multirow{3}{*}{\multicolumn{2}{|c|}{$\begin{array}{r}\mathrm{Au} \\
\text { Jan 11-Dec 13Co }\end{array}$}} & 0.947 & 0.133 & 0.651 & 0.683 & 0.427 & 0.561 & 0.306 & 0.444 & $\mathbf{0}$ \\
\hline & & 0.412 & 0.984 & 0.807 & 0.701 & 0.229 & $0.050^{*}$ & 0.161 & 0.258 & 1 \\
\hline & & 0.068 & $0.013^{*}$ & 0.207 & 0.076 & 0.300 & $0.050^{*}$ & $0.002 * *$ & 0.471 & 3 \\
\hline \multicolumn{2}{|c|}{$P d$} & $0.037 *$ & 0.131 & 0.569 & 0.313 & 0.130 & $0.001 * * *$ & 0.216 & 0.234 & 2 \\
\hline \multicolumn{2}{|c|}{$\frac{\mathrm{Pl}}{\text { \# of significant values }}$} & 0.164 & 0.526 & 0.253 & 0.151 & 0.059 & $0.009 * *$ & 0.504 & $0.000 * * *$ & 2 \\
\hline $\begin{array}{r}\# \text { of significa } \\
<0.0\end{array}$ & th values & 5 & 9 & 4 & 5 & 10 & 10 & 7 & 4 & 54 \\
\hline
\end{tabular}

Note:

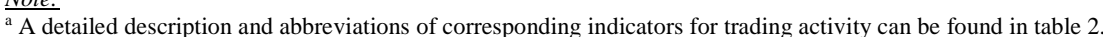

Estimating both directions of spot and trading activity relation, $5 a$ classifies the model: $X_{t}^{F}=\phi+\sum_{i=1}^{m} \lambda_{i} X_{t-i}^{F}+\sum_{i=1}^{n} \theta_{j} R_{t-i}^{S, V}+\varepsilon_{t}$ and, hence, $5 b$ the other direction: $R_{t}^{S, V}=$ $\phi+\sum_{i=1}^{m} \lambda_{i} R_{t-i}^{S, V}+\sum_{i=1}^{n} \theta_{j} X_{t-i}^{F}+\varepsilon_{t}$. The related lag-structure $(m, n)$ for each model is determined individually by the Akaike information criterion. The displayed $p$-values are from the F-tests of the null hypothesis $\theta_{j}=0 \forall F$ or $S, V$. Volatility $\mathrm{V}$ is calculated by the standard deviation from the previous five trading days.

${ }^{\mathrm{b}}$ The chemical symbols behind the abbreviation for the examined metals are as follows: Copper $(\mathrm{Cu})$, gold $(\mathrm{Au})$, palladium $(\mathrm{Pd})$, platinum $(\mathrm{Pt})$, and silver $(\mathrm{Ag})$. Significant values are highlighted $(*)$ denotes the $5 \%,(* *)$ the $1 \%$ and $(* * *)$ the $0.1 \%$ level.

${ }^{\mathrm{c}}$ For palladium, no data is available from August 2000 to September 2002. Therefore, the results for palladium for the full period are from September 2002 to December 2013. 


\section{$5 b$ - Spot price as dependent variable $($ SP $\leftarrow$ TP)}

\begin{tabular}{|c|c|c|c|c|c|c|c|c|c|c|}
\hline Period & Com. & $O I^{a}$ & NT & TRL & TRS & CL & CS & NCL & NCS & \\
\hline \multirow{5}{*}{$\begin{array}{l}\text { Jan } 93- \\
\text { Dec } 95\end{array}$} & $\mathrm{Ag}^{\mathrm{b}}$ & 0.637 & 0.537 & 0.783 & 0.628 & 0.678 & 0.357 & 0.293 & 0.264 & 0 \\
\hline & $\mathrm{Au}$ & 0.934 & 0.070 & 0.561 & 0.838 & 0.841 & 0.745 & 0.904 & 0.872 & $\mathbf{0}$ \\
\hline & $\mathrm{Co}$ & 0.414 & 0.615 & 0.616 & 0.478 & 0.707 & 0.809 & 0.750 & 0.400 & $\mathbf{0}$ \\
\hline & $\mathrm{Pd}^{\mathrm{c}}$ & 0.556 & 0.630 & 0.750 & 0.595 & 0.360 & 0.956 & 0.449 & 0.157 & $\mathbf{0}$ \\
\hline & $\mathrm{Pl}$ & 0.704 & 0.880 & 0.867 & 0.744 & 0.496 & 0.344 & 0.976 & 0.367 & $\mathbf{0}$ \\
\hline \multirow{3}{*}{\multicolumn{2}{|c|}{ Jan 96- Dec 98Co }} & 0.917 & 0.383 & 0.425 & 0.831 & 0.308 & 0.312 & 0.447 & 0.784 & 0 \\
\hline & & 0.772 & 0.119 & 0.273 & 0.588 & 0.497 & $0.033^{*}$ & 0.798 & 0.298 & $\mathbf{1}$ \\
\hline & & 0.322 & 0.506 & 0.662 & 0.168 & 0.720 & 0.128 & 0.761 & 0.799 & $\mathbf{0}$ \\
\hline & $\mathrm{Pd}$ & 0.900 & 0.385 & 0.517 & 0.869 & 0.248 & 0.746 & 0.736 & 0.449 & $\mathbf{0}$ \\
\hline & $\mathrm{Pl}$ & 0.258 & 0.310 & 0.109 & 0.452 & 0.056 & $0.015^{*}$ & 0.159 & 0.527 & 1 \\
\hline \multirow{3}{*}{\multicolumn{2}{|c|}{ Jan 99-Dec 01 Co }} & 0.552 & 0.210 & 0.283 & 0.476 & 0.803 & $0.009 * *$ & 0.118 & 0.167 & 1 \\
\hline & & 0.940 & 0.773 & 0.841 & 0.570 & 0.927 & 0.196 & 0.416 & $0.031 *$ & 1 \\
\hline & & 0.280 & $0.033^{*}$ & 0.272 & 0.179 & 0.180 & 0.135 & $0.024 *$ & 0.262 & 2 \\
\hline & $\mathrm{Pd}$ & I & I & I & I & I & I & I & I & I \\
\hline & $\mathrm{Pl}$ & 0.568 & 0.593 & 0.107 & 0.900 & 0.633 & 0.863 & 0.900 & 0.563 & 0 \\
\hline \multirow{3}{*}{\multicolumn{2}{|c|}{ Jan 02-Dec 04Co }} & 0.152 & 0.232 & 0.101 & 0.065 & 0.203 & 0.062 & 0.092 & 0.376 & $\mathbf{0}$ \\
\hline & & 0.539 & 0.884 & 0.849 & 0.882 & 0.663 & 0.705 & 0.893 & 0.926 & $\mathbf{0}$ \\
\hline & & 0.217 & 0.528 & 0.157 & 0.145 & 0.995 & 0.369 & 0.431 & 0.170 & $\mathbf{0}$ \\
\hline & $\mathrm{Pd}$ & I & I & I & I & I & I & I & I & I \\
\hline & $\mathrm{Pl}$ & 0.857 & 0.913 & 0.745 & 0.904 & 0.730 & 0.680 & 0.811 & 0.333 & $\mathbf{0}$ \\
\hline \multirow{3}{*}{\multicolumn{2}{|c|}{ Jan 05-Dec 07Co }} & 0.255 & 0.221 & 0.331 & 0.135 & 0.660 & 0.057 & 0.678 & 0.802 & o \\
\hline & & 0.675 & 0.975 & 0.691 & 0.814 & 0.353 & 0.562 & 0.541 & 0.363 & $\mathbf{0}$ \\
\hline & & 0.961 & 0.204 & 0.841 & 0.541 & 0.565 & 0.354 & 0.937 & 0.477 & $\mathbf{0}$ \\
\hline & $\mathrm{Pd}$ & $0.005 * *$ & $0.048 *$ & $0.001 * *$ & $0.002 * *$ & $0.000 * * *$ & $0.001 * * *$ & 0.778 & 0.448 & 6 \\
\hline & $\mathrm{Pl}$ & 0.525 & 0.642 & 0.509 & 0.520 & 0.361 & 0.551 & 0.974 & 0.696 & 0 \\
\hline \multirow{3}{*}{\multicolumn{2}{|c|}{ Jan 08-Dec 10Co }} & 0.682 & 0.123 & 0.927 & 0.814 & $0.023^{*}$ & 0.196 & $0.010 * *$ & 0.251 & 2 \\
\hline & & 0.278 & 0.743 & 0.145 & 0.100 & 0.262 & 0.155 & $0.039 *$ & $0.005 * *$ & 2 \\
\hline & & 0.124 & 0.213 & $0.026^{*}$ & $0.028 *$ & 0.604 & 0.181 & $0.008 * *$ & 0.299 & 3 \\
\hline \multicolumn{2}{|c|}{$P d$} & 0.558 & 0.705 & 0.146 & 0.308 & $0.044^{*}$ & 0.242 & 0.785 & 0.197 & 1 \\
\hline & $\mathrm{Pl}$ & $0.042 *$ & 0.299 & 0.142 & $0.047 *$ & $0.005 * *$ & $0.023 *$ & $0.037 *$ & $0.005 * *$ & 6 \\
\hline \multirow{3}{*}{\multicolumn{2}{|c|}{ Jan 11-Dec 13Co }} & 0.352 & 0.814 & 0.346 & 0.080 & 0.511 & 0.055 & 0.176 & 0.512 & 0 \\
\hline & & 0.758 & 0.367 & 0.358 & 0.095 & 0.242 & 0.780 & 0.965 & 0.503 & $\mathbf{0}$ \\
\hline & & 0.088 & 0.448 & 0.070 & 0.110 & $0.016^{*}$ & 0.191 & 0.401 & 0.244 & 1 \\
\hline \multicolumn{2}{|c|}{$\mathrm{Pd}$} & 0.752 & 0.576 & 0.339 & 0.400 & 0.258 & 0.295 & 0.749 & 0.266 & $\mathbf{0}$ \\
\hline \multicolumn{2}{|c|}{$\frac{\mathrm{Pl}}{\text { \# of significant values }}$} & 0.803 & 0.978 & 0.955 & 0.740 & 0.450 & 0.896 & 0.851 & 0.125 & $\mathbf{0}$ \\
\hline $\begin{array}{r}\# \text { of significa } \\
<0.0\end{array}$ & $\overline{\text { nt values }}$ & 2 & 2 & 2 & $\overline{3}$ & $\overline{5}$ & 5 & 5 & 3 & 27 \\
\hline
\end{tabular}

Note:

${ }^{a}$ A detailed description and abbreviations of corresponding indicators for trading activity can be found in table 2 .

Estimating both directions of spot and trading activity relation, $5 a$ classifies the model: $X_{t}^{F}=\phi+\sum_{i=1}^{m} \lambda_{i} X_{t-i}^{F}+\sum_{i=1}^{n} \theta_{j} R_{t-i}^{S, V}+\varepsilon_{t}$ and, hence, $5 b$ the other direction: $R_{t}^{S, V}=$ $\phi+\sum_{i=1}^{m} \lambda_{i} R_{t-i}^{S, V}+\sum_{i=1}^{n} \theta_{j} X_{t-i}^{F}+\varepsilon_{t}$. The related lag-structure $(m, n)$ for each model is determined individually by the Akaike information criterion. The displayed $p$-values are from the F-tests of the null hypothesis $\theta_{j}=0 \forall F$ or $S, V$. Volatility $\mathrm{V}$ is calculated by the standard deviation from the previous five trading days.

${ }^{\mathrm{b}}$ The chemical symbols behind the abbreviation for the examined metals are as follows: Copper (Cu), gold (Au), palladium (Pd), platinum (Pt), and silver (Ag). Significant values are highlighted $(*)$ denotes the $5 \%,(* *)$ the $1 \%$ and $(* * *)$ the $0.1 \%$ level.

${ }^{\mathrm{c}}$ For palladium, no data is available from August 2000 to September 2002. Therefore, the results for palladium for the full period are from September 2002 to December 2013. 
Table 6 - Overview of the results of bidirectional Granger-causality tests for subperiods - Volatility and absolute measures

6a - Volatility as independent variable (TPடVO)

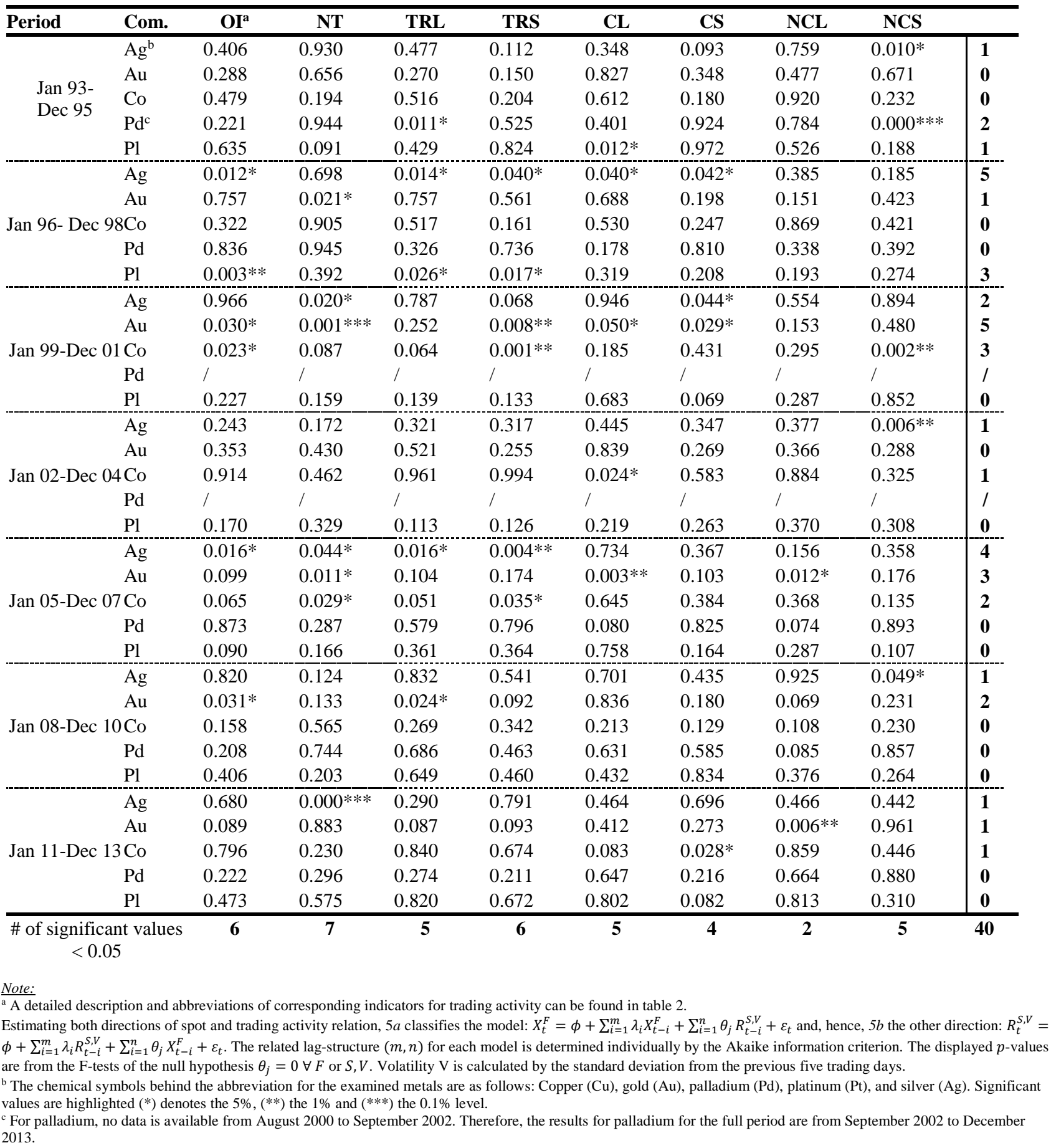


6b - Volatility as dependent variable (VO $\leftarrow$ TP)

\begin{tabular}{|c|c|c|c|c|c|c|c|c|c|c|}
\hline Period & Com. & $\mathrm{OI}^{\mathrm{a}}$ & NT & TRL & TRS & CL & $\mathrm{CS}$ & NCL & NCS & \\
\hline \multirow{5}{*}{$\begin{array}{l}\text { Jan 93- } \\
\text { Dec } 95\end{array}$} & $\mathrm{Ag}^{\mathrm{b}}$ & 0.075 & 0.996 & $0.048^{*}$ & 0.138 & 0.108 & 0.117 & 0.878 & 0.769 & 1 \\
\hline & $\mathrm{Au}$ & 0.067 & 0.072 & 0.134 & $0.028 *$ & 0.409 & 0.226 & 0.214 & 0.309 & 1 \\
\hline & $\mathrm{Co}$ & 0.155 & 0.054 & 0.423 & 0.390 & 0.704 & 0.365 & 0.672 & 0.138 & 0 \\
\hline & $\mathrm{Pd}^{\mathrm{c}}$ & 0.335 & 0.998 & 0.210 & 0.293 & 0.757 & 0.703 & $0.000 * * *$ & 0.553 & 1 \\
\hline & $\mathrm{Pl}$ & 0.754 & 0.635 & 0.787 & 0.702 & 0.155 & 0.087 & 0.059 & 0.167 & 0 \\
\hline \multirow{3}{*}{\multicolumn{2}{|c|}{$\begin{array}{r}\mathrm{Ag} \\
\mathrm{Au} \\
\text { Jan 96- Dec 98Co }\end{array}$}} & 0.768 & 0.938 & 0.636 & 0.702 & 0.090 & 0.503 & $0.015^{*}$ & 0.194 & 1 \\
\hline & & 0.404 & 0.574 & 0.515 & 0.514 & 0.767 & 0.420 & 0.375 & 0.908 & 0 \\
\hline & & 0.699 & 0.718 & 0.568 & 0.648 & 0.543 & 0.425 & 0.907 & 0.963 & 0 \\
\hline & $\mathrm{Pd}$ & 0.219 & 0.111 & 0.633 & 0.382 & 0.966 & 0.616 & 0.934 & 0.369 & 0 \\
\hline & $\mathrm{Pl}$ & 0.753 & 0.768 & 0.412 & 0.922 & 0.545 & 0.570 & 0.409 & 0.286 & 0 \\
\hline \multirow{3}{*}{\multicolumn{2}{|c|}{$\begin{array}{r}\mathrm{Ag} \\
\mathrm{Au} \\
\text { Jan 99-Dec 01 Co }\end{array}$}} & 0.796 & 0.951 & 0.477 & 0.096 & 0.253 & 0.290 & $0.022 *$ & 0.333 & 1 \\
\hline & & $0.031 *$ & $0.037 *$ & 0.243 & $0.039 *$ & 0.080 & 0.410 & $0.036^{*}$ & 0.086 & 4 \\
\hline & & 0.566 & 0.233 & 0.247 & 0.302 & 0.211 & 0.423 & 0.639 & 0.414 & 0 \\
\hline & $\mathrm{Pd}$ & I & I & I & I & I & I & I & I & I \\
\hline & $\mathrm{Pl}$ & 0.556 & 0.346 & 0.653 & 0.617 & $0.003 * *$ & 0.215 & $0.013 *$ & 0.880 & 2 \\
\hline \multirow{3}{*}{\multicolumn{2}{|c|}{$\begin{array}{r}\mathrm{Ag} \\
\mathrm{Au} \\
\text { Jan } 02-\operatorname{Dec} \text { 04 Co }\end{array}$}} & $0.026^{*}$ & 0.771 & $0.038^{*}$ & 0.087 & 0.421 & 0.175 & $0.031 *$ & 0.075 & 3 \\
\hline & & 0.569 & 0.460 & 0.527 & 0.382 & 0.356 & 0.448 & 0.317 & 0.711 & 0 \\
\hline & & 0.701 & 0.750 & 0.754 & 0.636 & 0.447 & 0.432 & 0.822 & 0.433 & 0 \\
\hline & $\mathrm{Pd}$ & I & I & I & I & I & I & I & I & I \\
\hline & $\mathrm{Pl}$ & 0.138 & $0.036^{*}$ & 0.105 & 0.061 & 0.274 & 0.078 & 0.199 & 0.352 & 1 \\
\hline \multirow{3}{*}{\multicolumn{2}{|c|}{$\begin{array}{r}\mathrm{Ag} \\
\mathrm{Au} \\
\text { Jan 05-Dec 07 Co }\end{array}$}} & 0.160 & 0.734 & 0.184 & 0.116 & 0.218 & 0.478 & 0.121 & 0.866 & 0 \\
\hline & & 0.468 & $0.037 *$ & 0.209 & 0.585 & 0.883 & 0.824 & 0.575 & 0.961 & 1 \\
\hline & & 0.323 & $0.020 *$ & 0.184 & 0.122 & $0.020 *$ & 0.729 & 0.186 & 0.384 & 2 \\
\hline & $\mathrm{Pd}$ & 0.646 & 0.497 & 0.680 & 0.693 & 0.470 & 0.777 & 0.551 & 0.814 & 0 \\
\hline & $\mathrm{Pl}$ & $0.009 * *$ & $0.022 *$ & $0.004 * *$ & $0.002 * *$ & 0.387 & $0.009^{* *}$ & $0.016^{*}$ & 0.345 & 6 \\
\hline \multirow{3}{*}{\multicolumn{2}{|c|}{$\begin{array}{r}\mathrm{Ag} \\
\mathrm{Au} \\
\text { Jan 08-Dec 10Co }\end{array}$}} & 0.885 & 0.249 & 0.947 & 0.902 & $0.018^{*}$ & 0.810 & $0.005^{* *}$ & 0.510 & 2 \\
\hline & & 0.332 & 0.100 & 0.281 & 0.119 & 0.377 & 0.589 & 0.539 & 0.108 & 0 \\
\hline & & 0.167 & 0.137 & 0.195 & 0.228 & 0.744 & 0.962 & 0.889 & 0.422 & $\mathbf{0}$ \\
\hline \multicolumn{2}{|c|}{$P d$} & 0.399 & 0.900 & 0.084 & 0.114 & 0.820 & $0.001 * * *$ & 0.108 & $0.031 *$ & 2 \\
\hline & $\mathrm{Pl}$ & 0.630 & 0.625 & 0.287 & 0.174 & 0.303 & 0.327 & 0.706 & 0.505 & 0 \\
\hline \multirow{3}{*}{\multicolumn{2}{|c|}{$\begin{array}{r}\mathrm{Ag} \\
\mathrm{Au} \\
\text { Jan 11-Dec 13Co }\end{array}$}} & 0.422 & 0.199 & 0.196 & 0.055 & 0.371 & $0.039^{*}$ & 0.103 & 0.731 & 1 \\
\hline & & 0.432 & 0.226 & 0.578 & 0.392 & 0.265 & 0.451 & 0.450 & 0.885 & $\mathbf{0}$ \\
\hline & & 0.428 & 0.129 & 0.345 & 0.349 & 0.842 & 0.185 & 0.547 & 0.229 & 0 \\
\hline \multicolumn{2}{|c|}{$\mathrm{Pd}$} & 0.696 & 0.830 & 0.665 & 0.569 & 0.158 & 0.350 & 0.120 & 0.423 & $\mathbf{0}$ \\
\hline \multicolumn{2}{|c|}{$\frac{\mathrm{Pl}}{\text { \# of significant values }}$} & 0.232 & 0.264 & 0.120 & 0.297 & 0.089 & 0.238 & 0.280 & 0.292 & $\mathbf{0}$ \\
\hline $\begin{array}{r}\text { of significe } \\
<0.0\end{array}$ & $\overline{\text { nt values }}$ & 3 & 5 & 3 & 3 & 3 & 3 & 8 & $\overline{1}$ & 29 \\
\hline
\end{tabular}

Note:

${ }^{\mathrm{a}}$ A detailed description and abbreviations of corresponding indicators for trading activity can be found in table 2.

Estimating both directions of spot and trading activity relation, $5 a$ classifies the model: $X_{t}^{F}=\phi+\sum_{i=1}^{m} \lambda_{i} X_{t-i}^{F}+\sum_{i=1}^{n} \theta_{j} R_{t-i}^{S, V}+\varepsilon_{t}$ and, hence, $5 b$ the other direction: $R_{t}^{S, V}=$ $\phi+\sum_{i=1}^{m} \lambda_{i} R_{t-i}^{S, V}+\sum_{i=1}^{n} \theta_{j} X_{t-i}^{F}+\varepsilon_{t}$. The related lag-structure $(m, n)$ for each model is determined individually by the Akaike information criterion. The displayed $p$-values are from the F-tests of the null hypothesis $\theta_{j}=0 \forall F$ or $S, V$. Volatility $\mathrm{V}$ is calculated by the standard deviation from the previous five trading days.

${ }^{\mathrm{b}}$ The chemical symbols behind the abbreviation for the examined metals are as follows: Copper $(\mathrm{Cu})$, gold $(\mathrm{Au})$, palladium $(\mathrm{Pd})$, platinum $(\mathrm{Pt})$, and silver $(\mathrm{Ag})$. Significant values are highlighted $(*)$ denotes the $5 \%,(* *)$ the $1 \%$ and $(* * *)$ the $0.1 \%$ level.

${ }^{\mathrm{c}}$ For palladium, no data is available from August 2000 to September 2002. Therefore, the results for palladium for the full period are from September 2002 to December 2013.

Furthermore, the results for the additional EGARCH volatility analysis of the full time frame are pre-

sented in table 7 . We initially note that the log-likelihood values for the unrestricted model and the model including the trading positions $(\mathrm{VO} \leftarrow \mathrm{TP})$ do not differ significantly; thus, the trading indicators do not seem to include much more information. Moreover, there are only three significant coefficients for the trading factors of silver, copper, and palladium. This is in slight contrast to the results of the Granger-causality in table $4 \mathrm{~b}$, in which at least eight significant causalities for these factors can be found. 
Unlike the Granger-causality tests, which utilize a weekly volatility derived from daily returns by using 5 day standard deviation, the EGARCH neglects intra-week returns, as volatility is estimated weekly due to the limited availability of daily CFTC indicators. Therefore, the results of this additional test indicate that most of the causalities leading from trading positions to volatility are visible during and are compensated after one week. This explanation is supported by yet another Granger-causality analysis of trading positions on EGARCH volatility, which leads to similar weak results ${ }^{2}$. Applying these additional tests, we can conclude that the estimated weekly volatility from daily returns in this context is a more appropriate measure than EGARCH volatilities, in order to recognize causalities between trading positions and volatility.

Table 7 -- Results of the EGARCH model with TP

\begin{tabular}{|c|c|c|c|c|c|}
\hline & $\mathbf{A g}^{\mathrm{b}}$ & Au & Co & $\mathbf{P d}^{\mathrm{c}}$ & PI \\
\hline $\begin{array}{l}\text { log-likelihood value } \\
\text { (unrestricted model) }\end{array}$ & 2064.965 & 2682.609 & 2171.613 & 949.8073 & 2367.98 \\
\hline $\begin{array}{l}\text { log-likelihood value } \\
\text { (TP model) }\end{array}$ & 2070.665 & 2687.313 & 2178.893 & 954.9695 & 2372.406 \\
\hline $\mathrm{P}$ & 4 & 3 & 5 & 1 & 3 \\
\hline Q & 1 & 1 & 2 & 1 & 2 \\
\hline$\beta_{1}(\mathrm{OI})^{\mathrm{a}}$ & -0.054 & 0.055 & $-0.108^{*}$ & 0.060 & 0.041 \\
\hline$\beta_{2}(\mathrm{NT})$ & 0.006 & 0.013 & 0.036 & -0.041 & 0.000 \\
\hline$\beta_{3}(\mathrm{NCL})$ & 0.011 & 0.002 & 0.005 & $-0.065^{*}$ & -0.002 \\
\hline$\beta_{4}(\mathrm{NCS})$ & $0.008 *$ & 0.004 & -0.009 & 0.001 & 0.001 \\
\hline$\beta_{5}(\mathrm{TRL})$ & 0.013 & -0.048 & 0.071 & 0.084 & -0.056 \\
\hline$\gamma_{1}$ & $0.150 * * *$ & $1.000 * *$ & 0.119 & $0.943 * * *$ & $-0.644 * * *$ \\
\hline$\gamma_{2}$ & $1.216 * * *$ & 0.748 & $0.448 * *$ & & $0.871 * * *$ \\
\hline$\gamma_{3}$ & $0.404 * * *$ & $-0.759 * *$ & 0.405 & & $0.657 * * *$ \\
\hline$\gamma_{4}$ & $-0.789 * * *$ & & 0.189 & & \\
\hline$\gamma_{5}$ & & & -0.211 & & \\
\hline$\xi_{1}$ & $0.129 * * *$ & $0.058 * * *$ & $0.247 * * *$ & $0.189 * * *$ & $0.363^{* * *}$ \\
\hline$\xi_{2}$ & & & 0.104 & & $0.393 * * *$ \\
\hline$\alpha_{1}$ & $-0.111 * * *$ & $-0.077 * * *$ & -0.336 & $-0.340^{*}$ & $-0.801 * * *$ \\
\hline$\alpha_{2}$ & & & 0.001 & & $0.002 * *$ \\
\hline$\kappa$ & 0.002 & 0.000 & $-0.087^{*}$ & 0.002 & $0.067 *$ \\
\hline$\mu$ & $0.047 * * *$ & -0.007 & $0.093^{*}$ & -0.025 & 0.048 \\
\hline
\end{tabular}

Note:

The table shows the coefficients of the estimated EGARCH model, whereby significances of the t-test are denoted as follows: ***=0,1\%; $* *=1 \%$; *=5\%

Estimating EGARCH, Formulas (3), (4) and (5) classify the model: $\log \sigma_{t}^{2}=\kappa+\sum_{i=1}^{P} \gamma_{i} \log \sigma_{t-i}^{2}+\sum_{j=1}^{Q} \alpha_{j}\left[\frac{\left|\varepsilon_{t-j}\right|}{\sigma_{t-j}}-E\left\{\frac{\left|\varepsilon_{t-j}\right|}{\sigma_{t-j}}\right\}\right]+\sum_{j=1}^{Q} \xi_{j}\left(\frac{\varepsilon_{t-j}}{\sigma_{t-j}}\right)$ with $\varepsilon_{t}=\sigma_{t} Z_{t}$ and $y_{t}=\mu+\varepsilon_{t}$

The related lag-structure $(P, Q)$ for each model is determined individually by an out-of-sample test.

${ }^{a}$ A detailed description and abbreviations of corresponding indicators for trading activity can be found in table 2 .

${ }^{\mathrm{b}}$ The chemical symbols behind the abbreviation for the examined metals are as follows: Copper $(\mathrm{Cu})$, gold (Au), palladium (Pd), platinum (Pt), and silver (Ag).

${ }^{\mathrm{c}}$ For palladium, no data is available from August 2000 to September 2002. Therefore, the results for palladium for the full period are from September 2002 to December 2013.

\footnotetext{
${ }^{2}$ These results, which are not reported (due to lack of space), are available upon request.
} 
All in all, it is difficult to draw a single cohesive conclusion from these rather distinct results. Regarding indicators of trading activity and differentiation between commercial and non-commercial positions, it is particularly difficult to find strong structural patterns. Nevertheless, we can state that trading activity is much more influenced by spot price development than the other way around. Volatility, in contrast, seems to be more influenced by commercial trading activity, especially for gold and silver. Furthermore, we find a number of interesting differences in relationships and behavior among the examined commodities.

\section{Robustness}

As a robustness check, we performed the entire series of Granger-causality tests with different frequencies, varying time sub-samples, alternative lag structures, and additional indicators. Concerning frequency, a second test series including more aggregated monthly data was implemented. Furthermore, we varied the sub-samples for monthly tests by up to eight and the weekly test by up to 18 sub-samples, with each considering the restriction of the minimum amount of observation points conducting the autoregressive Granger-causality analysis. As many studies use next-nearby futures as a proxy for spot prices, we also conducted our analysis with respective future price time series. For all of those adaptions, there were no significant differences concerning the main findings. Following some studies (e.g. Gilbert, 2010b; Mayer, 2012), we determined fixed lag structures of 12 weeks to conduct the tests, in which we basically observed the same results, but at a lower significance level.

Furthermore, in accordance with Irwin and Sanders (2010), we include additional relative measures by building ratios of open interest to number of traders, commercial and non-commercial positions to total reportable positions, again both long and short. These ratios are taken into account to capture size and change in the respective trading position, and thus offer potentially more explanation (see Table 8).

Table 8 - Overview of analyzed trading factors - ratios

\begin{tabular}{ccccc}
\hline \multicolumn{5}{c}{ relative measures } \\
\hline & ratio of commercial & ratio of commercial & ratio of non-commer- & ratio of non-commer- \\
ratio of open interest & long positions to total & short positions to & cial long positions to & cial short positions to \\
to number of traders & reportable long & total reportable short & total reportable long & total reportable short \\
& positions & positions & positions & positions \\
$(\mathrm{OI} / \mathrm{NT})$ & $(\mathrm{CL} / \mathrm{TRL})$ & $(\mathrm{CS} / \mathrm{TRS})$ & $(\mathrm{NCL} / \mathrm{TRL})$ & $(\mathrm{NCS} / \mathrm{TRS})$ \\
\hline
\end{tabular}


An additional absolute CFTC position, spread - the volume of equal combined-long and combinedshort positions of non-commercial traders - does not provide further insights. Another aspect, which substantiates the robustness of our results, is consistency between the results of the full time frame and the sub-samples. In conclusion, the overall picture of the results does not change. In all variations there are small indications that trading activity may influence volatility and spot price development, but no clear evidence. Also, considering the performed robustness checks, spot price development affecting trading behavior remains the most prevalent relationship.

\section{Discussion}

Our results generally show less evidence for trading positions substantially driving commodity prices and volatility. Conversely, we find stronger evidence for spot prices causing changes in traders' positions. These results show that market participants are intensely focused on price development, and behave as noise- or feedback traders. However, the overall results for both spot price and volatility do not show clear structural patterns regarding specific trading indicators. In this section, we first discuss our results compared to previous research, and show our overall contribution to recent literature and discussion. Subsequently, we describe aspects within the results, which are of special interest for our research. We further reflect on the pros and cons of the methodological framework.

According to the classification of Fattouh et al. (2013) of empirical literature on the influence of financialization, our results relate to the overlapping threads on the influence of futures trading positions on future prices, as well as the relationship between future and spot prices. Thereby, among other studies, our bi-directional analysis of spot prices and volatility in general supports the results of the strand researched by Sanders, Irwin et al. (2004, 2009, 2012), Büyükşahin and Harris (2009) and Brunetti and Büyükşahin (2009) for agricultural and energy markets, that there is overall no significant influence of trading activity on price levels. Our slightly stronger results for the effect on spot price volatility are also in line with the research of these authors. Our analysis thereby shows higher significance in the reverse direction, which has not been tested by the majority of authors. Thus, our results are also in line with the more-aggregated metals study of Mutafoglu et al. (2012). Considering the overall results, we assume metal markets to behave similar to other commodity markets. 
It is beneficial that this study is one of the few using actual spot prices, as physical commodities are reluctantly traded by non-commercial entities and spot prices are of special interest for the producing industry. Therefore, many other related studies use the next-nearby future as a proxy, which is less favorable in this context. Furthermore, our results contradict studies finding strong evidence for financialization, for instance by Gilbert (2010a, 2010b) or Mayer (2012). As our study uses a long time frame as well as smaller sub-samples within this full time frame, we are able to explain these differences. Due to this separation, we can see that the number of significant values is much higher within specific time samples than for the full time frame. This is obvious, for example, in the periods before and during the financial crisis, in which more evidence for trading positions, and thus financialization, is present, thereby causing changes in prices or volatility within specific and smaller periods. The use of different specific indicators to measure financial activity may also contribute to this ambiguity. For example, the approach of Mayer (2012) differs from the presented study, as he uses non-aggregated data for his Granger-causality analysis, thus identifying that money managers cause some price changes within gold and copper, but also finding indication for the reverse direction. Moreover, Gilbert (2010b), who finds evidence of financialization influencing non-metal commodity prices, uses similar methodological features, but applies more macroeconomic indicators. Therefore, with the utilization of a pure, broad, longterm, and consistent set of CFTC trading positions, we try to shed light on this issue.

Regarding underlying commodities, we find indication of different behavior between precious and nonprecious metals: Trading activity within the copper market seems to be much more affected by spot as well as volatility development, and volatility is vice versa less influenced by futures trading than all other (precious) metals. This might be due to the fact that copper is one of the most important commodities in global production. Unfortunately, there is no possibility of further validation, as aside from Gilbert's work (2010a), this study is one of the rare publications to include copper in the context of financialization. We furthermore observe that palladium and platinum prices are much more affected by trading activity than those of the other examined metals. The reason could be due to the much lower market size, compared to gold, silver, or copper.

Contrary to public perception, another quite interesting observation is that spot prices are not affected mainly by non-commercial positions, but by commercial and long positions. This chain of thought is in 
line with that of Sanders et al. (2004). These speculatively attributed non-commercial and long positions, however, show the highest impact among all variables in the volatility sub-sample analysis (VO $\rightarrow \mathrm{TP})$. Hence, it may be speculative traders driving volatility, but not prices themselves. This result is in line with findings from Brunetti and Büyükşahin (2009), Brunetti et al. (2011), and Irwin and Sanders (2010). Furthermore, we find small indications in line with results from Chatrath et al. (2003), who, by examining S\&P 500 futures, assume that speculative trading especially increases short-term liquidity, and thus causes higher changes in volatility than in pure prices,.

Moreover, regarding the time effects of financialization, we do not find signs of a long-term increase of significant relationships in the considered markets. Nevertheless, we find considerably more significant cases before and within crisis periods. Volatility seems to be more influenced by trading activity within the pre-crisis time period, whereas spot prices are the most influenced within the crisis, which supports the findings of Gilbert (2010b) for agriculture commodities.

Regarding the applied methodological frameworks, the Granger-causality analysis is commonly used in many studies on this subject, although it's restrictions and limitations should be taken into account. Issues in the context of financialization are addressed by Grosche (2012), as the application otherwise may lead to distortions or, at worst, wrong conclusions. According to this study, in order to capture potential correlations correctly, lag-structure based on theory is carefully assessed in our analysis using the Akaike criterion for each individual test. Additionally, though often not included, e.g. by Robles et al. (2009) or Gilbert (2010b), we consider the reverse causality in verifying our results. Nevertheless, when using the framework of the Granger-causality it is only possible to prove whether a variable provides statistically significant information about future values of another and vice versa, but not about the absolute influence, direction, and intensity. With regards to volatility analysis, we implement a supplemental EGARCH model not supporting the general influence of trading positions, which at best shows slight differences in details. This can be attributed to the differing measures of volatility. Whereas in the case of Granger-causality volatility analyses, standard deviation of daily returns is used, but the EGARCH models do not include this high frequency. EGARCH models in this context must be constructed weekly due to limited CFTC data, which is available only in a weekly frequency. 
With respect to these points and as we find some discernible trends, the use of alternative methods of investigation seems inevitable for future research. Concerning data, in comparison to other studies, we use the longest available time-sample from January 1993 to July 2013 on a weekly basis, as well as related sub-samples. Regardless, it might be possible to find stronger correlation and evidence using high-frequency data, as potential intra-week or even intra-day effects are not identifiable using weekly data (e.g. Mayer, 2012). In addition, the dynamical adjustments in the relationship between prices and inventory levels as shown by Geman and Smith (2013) could be examined with data of a higher frequency. To the best of our knowledge, COT reports are published only once a week. Moreover, since 2005, the CFTC publishes disaggregated COT reports, distinguishing between index traders, money managers, producers, and swap dealers. Though too short for a long-term analysis, such as the presented study, the disaggregated COT may offer more information.

All in all, the rather limited results for the influence of trading activity on spot prices indicate that there is little to no information imbalance between future and spot markets in the long term. As volatility is slightly more influenced by trading activity, one can assume that futures trading at least leads to a correcting reaction in the spot market. We find further strong evidence for prices and volatility causing changes in trading positions.

\section{Conclusion}

Focusing on the impact of financialization on metal commodity markets, we test if futures market trading activity causes significant changes in the price and volatility of spot markets and vice versa. Despite metals' fundamental importance to economy and industry, the influence of financialization on metal prices and volatility in particular is insufficiently studied. Therefore, by including copper, gold, platinum, palladium, and silver, we examine the full set of metals in the Commitment of Traders (COT) reports issued by the U.S. Commodity Futures Trading Commission (CFTC). We apply the established methodological framework of the Granger-causality to analyze if changes in commercial- and non-commercial traders' positions in future markets cause changes in spot prices and volatility and vice versa. Regarding the analysis of volatility, EGARCH models are additionally implemented. Thereby, a set of 
eight absolute measures is considered, representing pure trading activity on a weekly basis over the longest available period, from January 1993 to December 2013. Furthermore, the Granger-analysis is adopted for the entire timeframe as well as for ten subsamples, in order to capture possible short-term effects. Finally, we perform the entire series of Granger-causality tests with different frequencies, varying time sub-samples, and alternative lag structures as a robustness check.

Overall, we do find signs of trading positions influencing volatility to some extent, but find hardly any evidence of trading activity driving metal spot prices in the long-term. On the contrary, the Grangercausality tests calculated for the reverse direction show higher significance; therefore, spot price and volatility of metals drive trading positions more strongly. However, we find indications of price and volatility influencing effects of trading activity within sub-samples, such as phases of booms and crises. Contrary to public perception, non-commercial traders do not majorly affect price levels and volatility, but rather commercial and long traders have a greater impact. In general, there is less evidence that financialization influences commodity prices or volatility, which is also supported by the results of the EGARCH analyses. Further research should investigate whether the application of extending analysis methods, such as non-linear or panel Granger-analysis, provides more detailed results. Moreover, the CFTC has published since 2005 more disaggregated COT reports, distinguishing between index traders, money managers, producers, and swap dealers. Though too short for a long-term analysis, such as presented here, the disaggregated COT reports may be worth further examination vis-à-vis metals markets.

We hope that this work provides a valuable contribution to current discussion on the influence of financialization in commodity markets, as our research provides new evidence that financialization has little to no influence on metal price development in the long-term. 


\section{References}

Bessembinder, H., Seguin, P. J. (1993). Price Volatility, Trading Volume, and Market Depth: Evidence from Futures Markets. The Journal of Financial and Quantitative Analysis, 28(1), 21-39

Beveridge, S., Oickle, C. (1994). A Comparison of Box-Jenkins and objective methods for determining the order of a non-seasonal ARMA Model. Journal of Forecasting, 13(5), 419-434

Büyükşahin, B., Harris, J. (2009). The Role of Speculators in the Crude Oil Futures Market. CFTC, Working Paper.

Bohl, M. T., Stephan, P. M. (2013). Does Futures Speculation Destabilize Spot Prices? New Evidence for Commodity Markets. Journal of Agricultural and Applied Economics, 45(4), 595-616

Bohl, M. T., Javed, F., Stephan, P. M. (2012). Do Commodity Index Traders Destabilize Agricultural Futures Prices? Working Paper.

Brownlees, C., Engle, R., Kelly, B. (2012). A practical guide to volatility forecasting through calm and storm. Journal of Risk, 14(2), 3-22

Brunetti, C., Büyükşahin, B. (2009). Is Speculation Destabilizing? CFTC, Working Paper.

Brunetti, C., Büyükşahin, B., Harris, J. H. (2011). Speculators, prices and market volatility. Working Paper.

Bryant, H. L., Bessler, D. A., Haigh, M. S. (2006). Causality in Futures Markets. Journal of Futures Markets, 26(11), 1039-1057

Chatrath, A., Song, F., Adrangi, B. (2003). Futures trading activity and stock price volatility: Some extensions. Applied Financial Economics, 13(9), 655-664

Chatrath, A., Song, F. (1999). Futures Commitments and Commodity Price Jumps. The Financial Review, 34(3), 95-112

Cheng, I.-H., Xiong, W. (2014). Financialization of Commodity Markets. Annual Review of Financial Economics, 6, 419-441

CFTC (2008). Staff Report on Commodity Swap Dealers \& Index Traders with Commission Recommendations. Commodity Futures Trading Commission (September)

Fattouh, B., Kilian, L., Mahadeva, L. (2013). The Role of Speculation in Oil Markets: What Have We Learned So Far? The Energy Journal, 34(3), 7-33

Friedman, M. (1953). The Case for Flexible Exchange Rates. Essays in Positive Economics, University of Chicago Press, Chicago, 157-203 
Geman, H., Smith, W. O. (2013). Theory of storage, inventory and volatility in the LME base metals, Resources Policy, 38(1), 18-28

Gilbert, C. L. (2010a). Speculative Influences on commodity futures prices 2006-2008. United Nations Conference on Trade and Development (UNCTAD)

Gilbert, C. L. (2010b). How to Understand High Food Prices. Journal of Agricultural Economics, 61(2), $398-425$

Guida, T., Matringe, O. (2004). Application of GARCH models in forecasting the volatility of agricultural commodities, UNCTAD Publications.

Granger, C. W. J. (1969). Investigating Causal Relations by Econometric Models and Cross-spectral Methods. Econometrica, 37(3), 424-438

Grosche, S. (2012). Limitations of Granger Causality Analysis to assess the price effects from the financialization of agricultural commodity markets under bounded rationality. Discussion paper, Institute for Food and Resource Economics, University of Bonn

Harris, L. (1989). S\&P 500 Cash Stock Prices, Journal of Finance, 44(5), 1155-1175

Hicks, C. (1939). Value and Capital. Oxford University Press, Cambridge.

Irwin, S. H., Sanders, D. R. (2010). The Impact of Index and Swap Funds on Commodity Futures Markets: Preliminary Results". OECD Food, Agriculture and Fisheries Working Papers, No. 27, OECD Publishing.

Irwin, S. H., Sanders, D. R. (2012a). Testing the Masters Hypothesis in commodity futures markets. Energy Economics, 34(1), 256-269

Irwin, S. H., Sanders, D. R. (2012b). Financialization and Structural Change in Commodity Futures Markets. Journal of Agricultural and Applied Economics, 44(3), 371-396

Irwin, S. H., Sanders, D. R., Merrin, R. P. (2009). Devil or Angel? The Role of Speculation in the Recent Commodity Price Boom (and Bust). Journal of Agricultural and Applied Economics, 41(2), 377-391

Keynes, J. M. (1923). Some aspects of commodity markets. Manchester Guardian Commercial, European Reconstruction Series, Section 13, 784-786

Kim, A., (2015). Does Futures Speculation Destabilize Commodity Markets? Journal of Futures Markets, 35(8), 696-714

Kocagil, A. E. (1997). Does futures speculation stabilize spot prices? Evidence from metals markets. Applied Financial Economics, 7(1), 115-125

Lehecka, G. V. (2015). Do hedging and speculative pressures drive commodity prices, or the other way round? Empirical Economics, 49(2), 575-603 
Masters, M. W. (2008). Testimony before the Committee on Homeland Security and Governmental Affairs, United States Senate. (http://hsgac.senate.gov/public/_files/052008Masters.pdf).

Masters, M. W. (2009). Testimony before the Commodity Futures Trading Commission. (http://www.cftc.gov/ucm/groups/public/@newsroom/documents/file/hearing080509_masters.pdf).

Mayer, J. (2012). The Growing Financialization of Commodity Markets: Divergences between Index Investors and Money Managers. Journal of Development Studies, 48(6), 751-767

Mutafoglu, T. M (2012). Forecasting precious metal price movements using trader positions. Resources Policy, 37(3), 273-280

Robles, M., Torero, M., von Braun, J. (2009). When speculation matters. International Food Policy Research Institute, Issue Brief 57, Washington, DC.

Sanders, D. R., Boris, K., Manfredo, M. (2004). Hedgers, funds, and small speculators in the energy futures markets: an analysis of the CFTC's Commitments of Traders reports. Energy Economics, 26(3), $425-445$

Sanders, D. R., Irwin, S. H. (2010). A speculative bubble in commodity futures prices? Cross-sectional evidence. Agricultural Economics, 41(1), 25-32

Szado, E. (2011). Defining Speculation: The First Step toward a Rational Dialogue. The Journal of Alternative Investments, 14(1), 75-82

Tang, K. E., Xiong, W. (2012). Index Investment and the Financialization of Commodities. Financial Analysts Journal, 68(6), 54-74

Yang, J., Balyeat, R. B., Leatham, D. J. (2005). Futures Trading Activity and Commodity Cash Price Volatility. Journal of Business Finance \& Accounting, 32(1) \& (2), 297-323 


\section{Appendix}

Tables 9 - Overview of the results of bidirectional Granger-causality tests for the overall period - Spot price and relative measures

9a - Spot price as independent variable $(\mathrm{TP} \leftarrow \mathrm{SP})$

\begin{tabular}{|c|c|c|c|c|c|c|c|}
\hline Period & Com. & $\begin{array}{l}\text { OI/ } \\
\text { NT }\end{array}$ & $\begin{array}{l}\text { CL/ } \\
\text { TRL }\end{array}$ & $\begin{array}{l}\text { CS/ } \\
\text { TRS }\end{array}$ & $\begin{array}{l}\text { NCL/ } \\
\text { TRL }\end{array}$ & $\begin{array}{l}\text { NCS/ } \\
\text { TRS }\end{array}$ & \\
\hline \multirow{5}{*}{$\begin{array}{l}\text { Jan 93- } \\
\text { Dec } 13\end{array}$} & $\mathrm{Ag}^{\mathrm{b}}$ & 0.113 & $0.031 *$ & 0.061 & $0.006 * *$ & $0.000 * * *$ & 3 \\
\hline & $\mathrm{Au}$ & $0.020 *$ & 0.126 & 0.253 & 0.124 & 0.060 & 1 \\
\hline & Co & 0.366 & $0.006 * *$ & $0.002 * *$ & $0.000 * * *$ & $0.001 * *$ & 4 \\
\hline & $\mathrm{Pd}^{\mathrm{c}}$ & $0.001 * *$ & 0.115 & 0.140 & $0.000 * * *$ & $0.042 *$ & 3 \\
\hline & Pl & 0.520 & 0.276 & 0.328 & 0.520 & 0.214 & $\mathbf{0}$ \\
\hline \# of signif & des $<0$ & 2 & 2 & 1 & 3 & 3 & 11 \\
\hline
\end{tabular}

9b - Spot price as dependent variable (SP $\leftarrow$ TP)

\begin{tabular}{|c|c|c|c|c|c|c|c|}
\hline Period & Com. & $\begin{array}{l}\text { OI/ } \\
\text { NT }\end{array}$ & $\begin{array}{l}\text { CL/ } \\
\text { TRL }\end{array}$ & $\begin{array}{l}\text { CS/ } \\
\text { TRS }\end{array}$ & $\begin{array}{l}\text { NCL/ } \\
\text { TRL }\end{array}$ & $\begin{array}{l}\text { NCS/ } \\
\text { TRS }\end{array}$ & \\
\hline \multirow{5}{*}{$\begin{array}{l}\text { Jan 93- } \\
\text { Dec } 13\end{array}$} & $\mathrm{Ag}^{\mathrm{b}}$ & 0.455 & 0.905 & 0.811 & 0.986 & 0.963 & 0 \\
\hline & $\mathrm{Au}$ & 0.914 & $0.003 * *$ & 0.996 & 0.981 & 0.889 & 1 \\
\hline & Co & 0.268 & 0.328 & 0.408 & 0.619 & 0.605 & 0 \\
\hline & $\mathrm{Pd}^{\mathrm{c}}$ & 0.177 & $0.039 *$ & 0.272 & 0.353 & 0.873 & 1 \\
\hline & $\mathrm{Pl}$ & 0.339 & 0.320 & 0.599 & 0.320 & 0.973 & 0 \\
\hline
\end{tabular}

Note:

${ }^{a}$ A detailed description and abbreviations of corresponding indicators for trading activity can be found in table 8 .

Estimating both directions of spot and trading activity relation, $4 a$ classifies the model: $X_{t}^{F}=\phi+\sum_{i=1}^{m} \lambda_{i} X_{t-i}^{F}+\sum_{i=1}^{n} \theta_{j} R_{t-i}^{S, V}+\varepsilon_{t}$ and, hence, $4 b$ the other direction: $R_{t}^{S, V}=$ $\phi+\sum_{i=1}^{m} \lambda_{i} R_{t-i}^{S, V}+\sum_{i=1}^{n} \theta_{j} X_{t-i}^{F}+\varepsilon_{t}$. The related lag-structure $(m, n)$ for each model is determined individually by the Akaike information criterion. The displayed $p$-values are from the F-tests of the null hypothesis $\theta_{j}=0 \forall F$ or $S, V$.

${ }^{\mathrm{b}}$ The chemical symbols behind the abbreviation for the examined metals are as follows: Copper $(\mathrm{Cu})$, gold $(\mathrm{Au})$, palladium $(\mathrm{Pd})$, platinum $(\mathrm{Pt})$ and silver $(\mathrm{Ag})$. Significant values are highlighted: $(*)$ denotes the $5 \%,\left(^{* *}\right)$ the $1 \%$, and $(* * *)$ the $0.1 \%$ level.

${ }^{\mathrm{c}}$ For palladium, no data is available from August 2000 to September 2002. Therefore, the results for palladium for the full period are from September 2002 to December 2013 . 
Tables 10 - Overview of the results of bidirectional Granger-causality tests for the overall period - Volatility and relative measures

10a - Volatility as independent variable $(\mathrm{TP} \leftarrow \mathrm{VO})$

\begin{tabular}{|c|c|c|c|c|c|c|c|}
\hline Period & Com. & $\begin{array}{l}\text { OI/ } \\
\text { NT }\end{array}$ & $\begin{array}{l}\text { CL/ } \\
\text { TRL }\end{array}$ & $\begin{array}{l}\text { CS/ } \\
\text { TRS } \\
\end{array}$ & $\begin{array}{l}\text { NCL/ } \\
\text { TRL }\end{array}$ & $\begin{array}{l}\text { NCS/ } \\
\text { TRS }\end{array}$ & \\
\hline \multirow{5}{*}{$\begin{array}{l}\text { Jan 93- } \\
\text { Dec } 13\end{array}$} & $\mathrm{Ag}^{\mathrm{b}}$ & 0.667 & 0.208 & 0.916 & 0.059 & 0.505 & $\overline{0}$ \\
\hline & $\mathrm{Au}$ & $0.000 * * *$ & $0.029 *$ & 0.471 & $0.044 *$ & 0.129 & 3 \\
\hline & $\mathrm{Co}$ & 0.125 & $0.039 *$ & 0.198 & 0.104 & $0.003 * *$ & 2 \\
\hline & $\mathrm{Pd}^{\mathrm{c}}$ & 0.639 & 0.838 & 0.393 & 0.575 & 0.892 & $\mathbf{0}$ \\
\hline & $\mathrm{Pl}$ & 0.220 & 0.222 & 0.279 & 0.945 & 0.462 & 0 \\
\hline \# of signifi & $\overline{\text { lues }<0}$ & 1 & 2 & $\overline{0}$ & 1 & 1 & 5 \\
\hline
\end{tabular}

$10 \mathrm{~b}$ - Volatility as dependent variable (VO૯TP)

\begin{tabular}{|c|c|c|c|c|c|c|c|}
\hline Period & Com. & $\begin{array}{l}\text { OI/ } \\
\text { NT }\end{array}$ & $\begin{array}{l}\text { CL/ } \\
\text { TRL }\end{array}$ & $\begin{array}{l}\text { CS/ } \\
\text { TRS }\end{array}$ & $\begin{array}{l}\text { NCL/ } \\
\text { TRL }\end{array}$ & $\begin{array}{l}\text { NCS/ } \\
\text { TRS }\end{array}$ & \\
\hline \multirow{5}{*}{$\begin{array}{l}\text { Jan 93- } \\
\text { Dec } 13\end{array}$} & $\mathrm{Ag}^{\mathrm{b}}$ & 0.149 & $0.004 * *$ & 0.578 & 0.120 & $0.045^{*}$ & 2 \\
\hline & $\mathrm{Au}$ & $0.047 *$ & $0.010^{*}$ & $0.017 *$ & $0.000 * * *$ & 0.174 & 4 \\
\hline & Co & 0.053 & 0.474 & 0.294 & 0.111 & $0.000 * * *$ & 1 \\
\hline & $\mathrm{Pd}^{\mathrm{c}}$ & 0.804 & 0.718 & 0.135 & 0.512 & 0.539 & 0 \\
\hline & $\mathrm{Pl}$ & 0.864 & 0.224 & 0.731 & 0.634 & 0.117 & $\mathbf{0}$ \\
\hline \# of signifi & $\overline{\text { lues }<0}$ & 1 & 2 & 1 & 1 & 2 & 7 \\
\hline
\end{tabular}

Note:

${ }^{a}$ A detailed description and abbreviations of corresponding indicators for trading activity can be found intable 8

Estimating both directions of spot and trading activity relation, $5 a$ classifies the model: $X_{t}^{F}=\phi+\sum_{i=1}^{m} \lambda_{i} X_{t-i}^{F}+\sum_{i=1}^{n} \theta_{j} R_{t-i}^{S, V}+\varepsilon_{t}$ and, hence, $5 b$ the other direction: $R_{t}^{S, V}=$ $\phi+\sum_{i=1}^{m} \lambda_{i} R_{t-i}^{S, V}+\sum_{i=1}^{n} \theta_{j} X_{t-i}^{F}+\varepsilon_{t}$. The related lag-structure $(m, n)$ for each model is determined individually by the Akaike information criterion. The displayed $p$-values are from the F-tests of the null hypothesis $\theta_{j}=0 \forall F$ or $S, V$. Volatility $\mathrm{V}$ is calculated by the standard deviation from the previous five trading days.

${ }^{\mathrm{b}}$ The chemical symbols behind the abbreviation for the examined metals are as follows: Copper $(\mathrm{Cu})$, gold $(\mathrm{Au})$, palladium $(\mathrm{Pd})$, platinum $(\mathrm{Pt})$ and silver $(\mathrm{Ag})$. Significant values are highlighted $(*)$ denotes the $5 \%,(* *)$ the $1 \%$ and $(* * *)$ the $0.1 \%$ level.

${ }^{\mathrm{c}}$ For palladium, no data is available from August 2000 to September 2002. Therefore, the results for palladium for the full period are from September 2002 to December 2013. 
Tables 11 -- Overview of the results of bidirectional Granger-causality tests for subperiods - Spot price and relative measures

\section{1a - Spot price as independent variable $(\mathrm{TP} \leftarrow \mathrm{SP})$}

\begin{tabular}{|c|c|c|c|c|c|c|c|}
\hline Period & Com. & $\begin{array}{l}\text { OI/ } \\
\text { NT }\end{array}$ & $\begin{array}{l}\text { CL/ } \\
\text { TRL }\end{array}$ & $\begin{array}{l}\text { CS/ } \\
\text { TRS }\end{array}$ & $\begin{array}{l}\text { NCL/ } \\
\text { TRL }\end{array}$ & $\begin{array}{l}\text { NCS/ } \\
\text { TRS }\end{array}$ & \\
\hline \multirow{5}{*}{$\begin{array}{l}\text { Jan 93- } \\
\text { Dec } 95\end{array}$} & $\mathrm{Ag}^{\mathrm{b}}$ & 0.557 & 0.235 & 0.888 & 0.067 & 0.438 & 1 \\
\hline & $\mathrm{Au}$ & 0.746 & 0.984 & 0.548 & 0.416 & 0.790 & $\mathbf{0}$ \\
\hline & $\mathrm{Co}$ & 0.066 & 0.115 & $0.048 *$ & $0.002 * *$ & 0.129 & 3 \\
\hline & $\mathrm{Pd}^{\mathrm{c}}$ & 0.619 & 0.093 & 0.528 & 0.479 & 0.320 & $\mathbf{0}$ \\
\hline & $\mathrm{Pl}$ & 0.443 & 0.580 & 0.786 & 0.959 & 0.500 & 0 \\
\hline \multirow{5}{*}{ Jan 96- Dec 98} & $\mathrm{Ag}$ & 0.594 & 0.373 & 0.334 & 0.168 & 0.196 & 0 \\
\hline & $\mathrm{Au}$ & 0.692 & 0.542 & 0.396 & 0.407 & 0.370 & $\mathbf{0}$ \\
\hline & $\mathrm{Co}$ & 0.872 & $0.008 * *$ & 0.082 & $0.038 *$ & $0.000 * * *$ & 3 \\
\hline & $\mathrm{Pd}$ & 0.149 & $0.009 * *$ & 0.160 & 0.289 & 0.176 & 1 \\
\hline & $\mathrm{Pl}$ & 0.223 & $0.008 * *$ & 0.487 & 0.075 & 0.177 & 1 \\
\hline \multirow{5}{*}{ Jan 99-Dec 01} & $\mathrm{Ag}$ & 0.253 & $0.001 * * *$ & $0.000 * * *$ & $0.014 *$ & $0.004 * *$ & 5 \\
\hline & $\mathrm{Au}$ & 0.619 & 0.940 & 0.175 & 0.192 & 0.237 & $\mathbf{0}$ \\
\hline & $\mathrm{Co}$ & 0.593 & $0.001 * *$ & $0.006 * *$ & $0.000 * * *$ & $0.027 *$ & 5 \\
\hline & $\mathrm{Pd}$ & I & / & I & / & I & I \\
\hline & $\mathrm{Pl}$ & 0.985 & 0.921 & 0.674 & 0.746 & 0.813 & $\mathbf{0}$ \\
\hline \multirow{5}{*}{ Jan 02-Dec 04} & $\mathrm{Ag}$ & $0.004 * *$ & 0.337 & $0.045^{*}$ & 0.144 & $0.000 * * *$ & 4 \\
\hline & $\mathrm{Au}$ & $0.001 * * *$ & 0.247 & 0.758 & 0.484 & 0.784 & 1 \\
\hline & $\mathrm{Co}$ & 0.953 & 0.372 & 0.209 & 0.205 & 0.115 & $\mathbf{0}$ \\
\hline & $\mathrm{Pd}$ & / & / & / & I & / & l \\
\hline & $\mathrm{Pl}$ & 0.564 & $0.006^{* *}$ & 0.774 & $0.016^{*}$ & $0.044 *$ & 4 \\
\hline \multirow{5}{*}{ Jan 05-Dec 07} & $\mathrm{Ag}$ & $0.047 *$ & 0.770 & 0.421 & 0.890 & 0.222 & 1 \\
\hline & $\mathrm{Au}$ & 0.052 & 0.795 & 0.918 & 0.468 & 0.474 & $\mathbf{0}$ \\
\hline & $\mathrm{Co}$ & 0.148 & 0.842 & 0.911 & 0.407 & 0.689 & $\mathbf{0}$ \\
\hline & $\mathrm{Pd}$ & $0.009 * *$ & $0.015^{*}$ & 0.334 & 0.104 & 0.411 & 2 \\
\hline & $\mathrm{Pl}$ & $0.047 *$ & 0.433 & 0.262 & $0.001 * * *$ & 0.775 & 2 \\
\hline \multirow{5}{*}{ Jan 08-Dec 10} & $\mathrm{Ag}$ & 0.608 & 0.503 & 0.363 & 0.439 & 0.245 & 0 \\
\hline & $\mathrm{Au}$ & 0.871 & $0.027 *$ & $0.041 *$ & $0.025 *$ & $0.018^{*}$ & 4 \\
\hline & Co & $0.010 * *$ & 0.187 & $0.006^{* *}$ & 0.809 & 0.315 & 2 \\
\hline & $\mathrm{Pd}$ & 0.569 & 0.083 & 0.892 & 0.228 & 0.561 & $\mathbf{0}$ \\
\hline & $\mathrm{Pl}$ & 0.277 & 0.690 & 0.172 & 0.319 & $0.028 *$ & 1 \\
\hline \multirow{5}{*}{ Jan 11-Dec 13} & $\mathrm{Ag}$ & 0.315 & 0.071 & 0.453 & 0.476 & 0.433 & 0 \\
\hline & $\mathrm{Au}$ & 0.117 & 0.583 & $0.014 *$ & 0.540 & 0.179 & 1 \\
\hline & $\mathrm{Co}$ & 0.632 & $0.044 *$ & 0.483 & $0.007 * *$ & 0.761 & 3 \\
\hline & $\mathrm{Pd}$ & 0.954 & 0.158 & $0.047 *$ & 0.556 & 0.099 & 1 \\
\hline & $\mathrm{Pl}$ & $0.000 * * *$ & 0.094 & $0.004 * *$ & 0.101 & $0.000 * * *$ & 3 \\
\hline \# of significant & alues $<0$ & 7 & 9 & 9 & 8 & 8 & 41 \\
\hline
\end{tabular}

Note:

${ }^{a}$ A detailed description and abbreviations of corresponding indicators for trading activity can be found intable 8 .

Estimating both directions of spot and trading activity relation, $5 a$ classifies the model: $X_{t}^{F}=\phi+\sum_{i=1}^{m} \lambda_{i} X_{t-i}^{F}+\sum_{i=1}^{n} \theta_{j} R_{t-i}^{S, V}+\varepsilon_{t}$ and, hence, $5 b$ the other direction: $R_{t}^{S, V}=$ $\phi+\sum_{i=1}^{m} \lambda_{i} R_{t-i}^{S, V}+\sum_{i=1}^{n} \theta_{j} X_{t-i}^{F}+\varepsilon_{t}$. The related lag-structure $(m, n)$ for each model is determined individually by the Akaike information criterion. The displayed $p$-values are from the F-tests of the null hypothesis $\theta_{j}=0 \forall F$ or $S, V$. Volatility $\mathrm{V}$ is calculated by the standard deviation from the previous five trading days.

${ }^{\mathrm{b}}$ The chemical symbols behind the abbreviation for the examined metals are as follows: Copper $(\mathrm{Cu})$, gold $(\mathrm{Au})$, palladium $(\mathrm{Pd})$, platinum $(\mathrm{Pt})$ and silver $(\mathrm{Ag})$. Significant values are highlighted $(*)$ denotes the $5 \%,(* *)$ the $1 \%$ and $(* * *)$ the $0.1 \%$ level.

${ }^{\mathrm{c}}$ For palladium, no data is available from August 2000 to September 2002. Therefore, the results for palladium for the full period are from September 2002 to December 2013. 
$11 b$ - Spot price as dependent variable $(\mathrm{SP} \leftarrow \mathrm{TP})$

\begin{tabular}{|c|c|c|c|c|c|c|c|}
\hline Period & Com. & $\begin{array}{l}\text { OI/ } \\
\text { NT }\end{array}$ & $\begin{array}{l}\text { CL/ } \\
\text { TRL }\end{array}$ & $\begin{array}{l}\text { CS/ } \\
\text { TRS }\end{array}$ & $\begin{array}{l}\text { NCL/ } \\
\text { TRL }\end{array}$ & $\begin{array}{l}\text { NCS/ } \\
\text { TRS }\end{array}$ & \\
\hline \multirow{5}{*}{$\begin{array}{l}\text { Jan 93- } \\
\text { Dec } 95\end{array}$} & $\mathrm{Ag}^{\mathrm{b}}$ & 0.965 & 0.930 & 0.409 & 0.666 & 0.263 & $\overline{0}$ \\
\hline & $\mathrm{Au}$ & 0.148 & 0.444 & 0.820 & 0.607 & 0.842 & 0 \\
\hline & $\mathrm{Co}$ & 0.275 & 0.983 & 0.223 & 0.953 & 0.370 & 0 \\
\hline & $\mathrm{Pd}^{\mathrm{c}}$ & 0.658 & 0.308 & 0.837 & 0.214 & 0.462 & 0 \\
\hline & $\mathrm{Pl}$ & 0.520 & 0.866 & 0.544 & 0.313 & 0.365 & $\mathbf{0}$ \\
\hline \multirow{5}{*}{ Jan 96- Dec 98} & $\mathrm{Ag}$ & 0.877 & 0.211 & 0.369 & 0.130 & 0.800 & 0 \\
\hline & $\mathrm{Au}$ & 0.440 & 0.477 & 0.094 & 0.990 & 0.494 & $\mathbf{0}$ \\
\hline & $\mathrm{Co}$ & 0.983 & 0.228 & 0.154 & 0.438 & 0.856 & 0 \\
\hline & $\mathrm{Pd}$ & 0.406 & 0.448 & 0.476 & 0.172 & 0.082 & $\mathbf{0}$ \\
\hline & $\mathrm{Pl}$ & 0.978 & 0.318 & $0.044 *$ & $0.021 *$ & 0.530 & 2 \\
\hline \multirow{5}{*}{ Jan 99-Dec 01} & $\mathrm{Ag}$ & 0.086 & 0.320 & 0.159 & 0.400 & 0.072 & 0 \\
\hline & $\mathrm{Au}$ & 0.255 & 0.133 & 0.196 & 0.381 & 0.092 & 0 \\
\hline & $\mathrm{Co}$ & 0.851 & 0.115 & 0.880 & 0.200 & 0.180 & 0 \\
\hline & $\mathrm{Pd}$ & I & I & I & / & / & I \\
\hline & $\mathrm{Pl}$ & 0.899 & 0.672 & 0.782 & 0.849 & 0.570 & 0 \\
\hline \multirow{5}{*}{ Jan 02-Dec 04} & $\mathrm{Ag}$ & 0.990 & 0.239 & 0.552 & 0.385 & 0.238 & 0 \\
\hline & $\mathrm{Au}$ & 0.156 & 0.853 & 0.493 & 0.843 & 0.931 & 0 \\
\hline & Co & 0.244 & 0.241 & 0.405 & 0.827 & 0.236 & 0 \\
\hline & $\mathrm{Pd}$ & I & / & I & / & l & I \\
\hline & $\mathrm{Pl}$ & 0.975 & 0.848 & 0.495 & 0.614 & 0.536 & $\mathbf{0}$ \\
\hline \multirow{5}{*}{ Jan 05-Dec 07} & $\mathrm{Ag}$ & 0.306 & 0.380 & 0.320 & 0.783 & 0.670 & 0 \\
\hline & $\mathrm{Au}$ & 0.837 & 0.512 & 0.252 & 0.223 & 0.440 & 0 \\
\hline & $\mathrm{Co}$ & 0.069 & 0.961 & 0.183 & 0.985 & 0.257 & 0 \\
\hline & $\mathrm{Pd}$ & $0.000 * * *$ & $0.000 * * *$ & 0.352 & $0.018 *$ & 0.125 & 3 \\
\hline & $\mathrm{Pl}$ & 0.100 & 0.491 & 0.350 & 0.173 & 0.852 & 0 \\
\hline \multirow{5}{*}{ Jan 08-Dec 10} & $\mathrm{Ag}$ & 0.251 & $0.005 * *$ & 0.125 & $0.005 * *$ & 0.214 & 2 \\
\hline & $\mathrm{Au}$ & 0.187 & 0.370 & 0.719 & 0.389 & $0.012 *$ & 1 \\
\hline & $\mathrm{Co}$ & 0.826 & $0.035^{*}$ & 0.560 & $0.047 *$ & 0.491 & 2 \\
\hline & $\mathrm{Pd}$ & 0.888 & 0.078 & 0.566 & 0.893 & 0.393 & 0 \\
\hline & $\mathrm{Pl}$ & 0.832 & 0.059 & $0.000 * * *$ & 0.120 & $0.007 * *$ & 2 \\
\hline \multirow{5}{*}{ Jan 11-Dec 13} & $\mathrm{Ag}$ & 0.697 & 0.898 & 0.995 & 0.489 & 0.630 & 0 \\
\hline & $\mathrm{Au}$ & $0.045^{*}$ & 0.688 & 0.259 & 0.762 & 0.629 & 1 \\
\hline & Co & 0.409 & 0.358 & 0.832 & 0.560 & 0.780 & 0 \\
\hline & $\mathrm{Pd}$ & 0.179 & 0.358 & 0.191 & 0.214 & 0.256 & 0 \\
\hline & $\mathrm{Pl}$ & 0.837 & 0.464 & 0.579 & 0.676 & 0.182 & $\mathbf{0}$ \\
\hline$\#$ of significant & alues $<$ & 2 & 3 & 2 & 4 & 2 & 13 \\
\hline
\end{tabular}

Note:

a detailed description and abbreviations of corresponding indicators for trading activity can be found intable 8 .

Estimating both directions of spot and trading activity relation, $5 a$ classifies the model: $X_{t}^{F}=\phi+\sum_{i=1}^{m} \lambda_{i} X_{t-i}^{F}+\sum_{i=1}^{n} \theta_{j} R_{t-i}^{S, V}+\varepsilon_{t}$ and, hence, $5 b$ the other direction: $R_{t}^{S, V}=$ $\phi+\sum_{i=1}^{m} \lambda_{i} R_{t-i}^{S, V}+\sum_{i=1}^{n} \theta_{j} X_{t-i}^{F}+\varepsilon_{t}$. The related lag-structure $(m, n)$ for each model is determined individually by the Akaike information criterion. The displayed $p$-values are from the F-tests of the null hypothesis $\theta_{j}=0 \forall F$ or $S, V$. Volatility $\mathrm{V}$ is calculated by the standard deviation from the previous five trading days.

${ }^{\mathrm{b}}$ The chemical symbols behind the abbreviation for the examined metals are as follows: Copper $(\mathrm{Cu})$, gold $(\mathrm{Au})$, palladium $(\mathrm{Pd})$, platinum $(\mathrm{Pt})$ and silver $(\mathrm{Ag})$. Significant values are highlighted $(*)$ denotes the $5 \%,(* *)$ the $1 \%$ and $(* * *)$ the $0.1 \%$ level.

${ }^{\mathrm{c}}$ For palladium, no data is available from August 2000 to September 2002. Therefore, the results for palladium for the full period are from September 2002 to December 2013. 
12b - Volatility as dependent variable (VO૯TP)

\begin{tabular}{|c|c|c|c|c|c|c|c|}
\hline Period & Com. & $\begin{array}{l}\text { OI/ } \\
\text { NT }\end{array}$ & $\begin{array}{l}\text { CL/ } \\
\text { TRL }\end{array}$ & $\begin{array}{l}\text { CS/ } \\
\text { TRS }\end{array}$ & $\begin{array}{l}\text { NCL/ } \\
\text { TRL }\end{array}$ & $\begin{array}{l}\text { NCS/ } \\
\text { TRS }\end{array}$ & \\
\hline \multirow{5}{*}{$\begin{array}{l}\text { Jan 93- } \\
\text { Dec } 95\end{array}$} & $\mathrm{Ag}^{\mathrm{b}}$ & 0.336 & 0.328 & 0.839 & 0.804 & 0.737 & $\overline{0}$ \\
\hline & $\mathrm{Au}$ & $0.023 *$ & 0.249 & 0.426 & 0.614 & 0.273 & $\mathbf{1}$ \\
\hline & Co & $0.020 *$ & 0.884 & 0.520 & 0.667 & 0.167 & $\mathbf{1}$ \\
\hline & $\mathrm{Pd}^{\mathrm{c}}$ & 0.478 & 0.124 & 0.967 & $0.000 * * *$ & 0.908 & 1 \\
\hline & $\mathrm{Pl}$ & 0.246 & 0.152 & $0.031 *$ & 0.069 & 0.108 & 1 \\
\hline \multirow{5}{*}{ Jan 96- Dec 98} & $\mathrm{Ag}$ & 0.548 & $0.018^{*}$ & 0.577 & $0.001 * * *$ & 0.179 & 2 \\
\hline & $\mathrm{Au}$ & 0.900 & 0.918 & 0.245 & 0.254 & 0.929 & $\mathbf{0}$ \\
\hline & $\mathrm{Co}$ & 0.253 & 0.928 & 0.761 & 0.864 & 0.898 & $\mathbf{0}$ \\
\hline & $\mathrm{Pd}$ & 0.185 & 0.587 & 0.431 & 0.948 & 0.394 & $\mathbf{0}$ \\
\hline & $\mathrm{Pl}$ & 0.251 & 0.502 & 0.309 & 0.704 & 0.340 & $\mathbf{0}$ \\
\hline \multirow{5}{*}{ Jan 99-Dec 01} & $\mathrm{Ag}$ & 0.517 & 0.077 & 0.854 & 0.630 & 0.210 & 0 \\
\hline & $\mathrm{Au}$ & 0.203 & $0.024 *$ & $0.021 *$ & 0.071 & 0.347 & 2 \\
\hline & Co & 0.135 & 0.295 & 0.597 & 0.594 & 0.373 & $\mathbf{0}$ \\
\hline & $\mathrm{Pd}$ & I & I & I & I & l & I \\
\hline & $\mathrm{Pl}$ & 0.943 & $0.001 * * *$ & 0.239 & $0.025^{*}$ & 0.893 & 2 \\
\hline \multirow{5}{*}{ Jan 02-Dec 04} & $\mathrm{Ag}$ & 0.167 & 0.124 & 0.134 & 0.242 & 0.057 & 0 \\
\hline & $\mathrm{Au}$ & 0.803 & 0.339 & 0.839 & 0.358 & 0.880 & 0 \\
\hline & Co & 0.323 & 0.442 & 0.542 & 0.848 & 0.331 & $\mathbf{0}$ \\
\hline & $\mathrm{Pd}$ & l & l & l & I & l & I \\
\hline & $\mathrm{Pl}$ & 0.182 & 0.293 & 0.528 & 0.575 & 0.381 & $\mathbf{0}$ \\
\hline \multirow{5}{*}{ Jan 05-Dec 07} & $\mathrm{Ag}$ & $0.044 *$ & 0.085 & 0.970 & $0.034 *$ & 0.915 & 2 \\
\hline & $\mathrm{Au}$ & 0.203 & 0.597 & 0.619 & 0.427 & 0.978 & $\mathbf{0}$ \\
\hline & $\mathrm{Co}$ & $0.028 *$ & 0.060 & 0.906 & 0.129 & 0.956 & $\mathbf{1}$ \\
\hline & $\mathrm{Pd}$ & 0.229 & 0.785 & 0.909 & 0.194 & 0.214 & $\mathbf{0}$ \\
\hline & $\mathrm{Pl}$ & 0.285 & $0.036^{*}$ & 0.200 & $0.008 * *$ & 0.499 & 2 \\
\hline \multirow{5}{*}{ Jan 08-Dec 10} & $\mathrm{Ag}$ & 0.089 & $0.001 * * *$ & 0.274 & $0.004 * *$ & 0.451 & 2 \\
\hline & $\mathrm{Au}$ & $0.021 *$ & 0.678 & 0.906 & 0.846 & 0.161 & 1 \\
\hline & Co & 0.087 & 0.197 & 0.608 & 0.900 & 0.927 & $\mathbf{0}$ \\
\hline & $\mathrm{Pd}$ & 0.918 & 0.724 & $0.000 * * *$ & 0.090 & $0.004 * *$ & 2 \\
\hline & $\mathrm{Pl}$ & 0.786 & 0.658 & 0.066 & 0.881 & 0.259 & $\mathbf{0}$ \\
\hline \multirow{5}{*}{ Jan 11-Dec 13} & $\mathrm{Ag}$ & 0.164 & $0.016^{*}$ & 0.475 & 0.748 & 0.519 & 1 \\
\hline & $\mathrm{Au}$ & 0.086 & 0.126 & 0.887 & 0.619 & 0.977 & $\mathbf{0}$ \\
\hline & Co & 0.758 & 0.170 & 0.073 & 0.480 & 0.152 & $\mathbf{0}$ \\
\hline & $\mathrm{Pd}$ & 0.561 & 0.120 & 0.405 & 0.179 & 0.300 & 0 \\
\hline & $\mathrm{Pl}$ & 0.278 & 0.070 & 0.227 & $0.012 *$ & 0.233 & 1 \\
\hline
\end{tabular}

Note:

a A detailed description and abbreviations of corresponding indicators for trading activity can be foundtable 8 .

Estimating both directions of spot and trading activity relation, $5 a$ classifies the model: $X_{t}^{F}=\phi+\sum_{i=1}^{m} \lambda_{i} X_{t-i}^{F}+\sum_{i=1}^{n} \theta_{j} R_{t-i}^{S, V}+\varepsilon_{t}$ and, hence, $5 b$ the other direction: $R_{t}^{S, V}=$ $\phi+\sum_{i=1}^{m} \lambda_{i} R_{t-i}^{S, V}+\sum_{i=1}^{n} \theta_{j} X_{t-i}^{F}+\varepsilon_{t}$. The related lag-structure $(m, n)$ for each model is determined individually by the Akaike information criterion. The displayed $p$-values are from the F-tests of the null hypothesis $\theta_{j}=0 \forall F$ or $S, V$. Volatility $\mathrm{V}$ is calculated by the standard deviation from the previous five trading days.

${ }^{b}$ The chemical symbols behind the abbreviation for the examined metals are as follows: Copper $(\mathrm{Cu})$, gold $(\mathrm{Au})$, palladium $(\mathrm{Pd})$, platinum $(\mathrm{Pt})$ and silver $(\mathrm{Ag})$. Significant values are highlighted $(*)$ denotes the $5 \%,(* *)$ the $1 \%$ and $(* * *)$ the $0.1 \%$ level.

${ }^{\mathrm{c}}$ For palladium, no data is available from August 2000 to September 2002. Therefore, the results for palladium for the full period are from September 2002 to December 2013. 